\title{
O ESTADO DA ARTE DAS PESQUISAS EM ENSINO DE GEOGRAFIA QUE DISCUTEM A QUESTÃO RACIAL NO BRASIL
}

\author{
THE STATE OF THE ART OF RESEARCH IN GEOGRAPHY TEACHING \\ THAT DISCUSSES THE RACIAL ISSUE IN BRAZIL
}

\section{EL ESTADO DEL ARTE DE LA INVESTIGACIÓN EN LA ENSEÑANZA DE LA GEOGRAFÍA QUE TRATA EL TEMA RACIAL EN BRASIL}

\begin{abstract}
Ana Carolina dos Santos Marques
Especialista em Ensino de Geografia pela Universidade Estadual de Londrina (UEL). Mestranda no Programa de Pós-Graduação em Geografia da Faculdade de Ciências e Tecnologia - Universidade Estadual Júlio de Mesquita Filho (FCT/UNESP), Campus de Presidente Prudente. E-mail: anaaao@ hotmail.com
\end{abstract}

\section{Ricardo Lopes Fonseca}

Doutor em Geografia pelo Programa de Pós-Graduação em Geografia da Universidade Estadual de Londrina (UEL). Docente do Departamento de Geociências da Universidade Estadual de Londrina. E-mail: ricardolopesfonseca@hotmail.com

\section{Resumo}

A educação se evidencia como um dos instrumentos com maior potencial na luta pela superação do racismo. Ao pensarmos no ensino de geografia, defendemos que ele pode contribuir para o debate racial e a busca pela igualdade racial. Compreender como este debate tem sido feito, no Brasil, é fundamental. Assim, esta pesquisa objetiva realizar o estado da arte da questão racial no ensino de geografia a fim de compreender de que forma esta questão tem sido discutida, nos artigos publicados em periódicos, dissertações e teses de ensino de geografia. Este estado da arte foi realizado por meio da verificação em periódicos nacionais e de uma busca no Catálogo de Teses e Dissertações da CAPES. As pesquisas encontradas foram analisadas e categorizadas, com base na análise textual discursiva (SOUSA, GALIAZZI, 2017) e na análise de conteúdo (BARDIN, 1977). O panorama da produção científica investigada revela uma escassez da discussão racial no ensino de geografia, no Brasil, sendo encontradas 29 pesquisas apontando para a emergência desta discussão.

Palavras-chave: questão racial, ensino de geografia, estado da arte, Brasil.

D

D D p.86-122, V.15, n.28, set./dez. 2019. 


\section{Abstract}

Education is qualified as one of the instruments with the greatest potential in the struggle to overcome racism. By thinking about geography teaching, we support that it might contribute to the racial debate and to the search for racial equality. It is fundamental to understand how this debate has been conducted, in Brazil. Therefore this research aims to realize the state of the art of the racial issue in the teaching of geography to understand how the issue has been discussed in articles published in Brazilian journals, theses and dissertations of geography teaching. This state of the art was performed by checking national journals and searching the CAPES Catalog of Theses and Dissertations. The research found was analyzed and categorized based on discursive textual analysis (SOUSA, GALIAZZI, 2017) and content analysis (BARDIN, 1977). The panorama of the scientific production investigated reveals a lack of racial discussion in the teaching of geography in Brazil, with only 29 studies found, pointing to the emergence of this discussion.

Keywords: racial issue, geography teaching, state of the art, Brazil.

\section{Resumen}

La educación es evidente como uno de los instrumentos con mayor potencial en la lucha para superar el racismo. Pensando en la enseñanza de la geografía, argumentamos que la misma puede contribuir al debate racial y a la búsqueda por igualdad racial. Comprender cómo se ha llevado a cabo este debate en Brasil es fundamental. Por lo tanto, esta investigación tiene como objetivo realizar el estado del arte de la cuestión racial en la enseñanza de la geografía para comprender cómo se ha discutido esta cuestión en artículos publicados en revistas, disertaciones y tesis docentes de geografía. Este estado del arte se ha logrado verificando revistas nacionales y buscando en el Catálogo de Tesis y Disertaciones de CAPES. Las investigaciones encontradas fueron analizadas y clasificadas en base al análisis textual discursivo (SOUSA, GALIAZZI, 2017) y al análisis de contenido (BARDIN, 1977). El panorama de la producción científica investigada revela una falta de discusión racial en la enseñanza de la geografía en Brasil, con solo 29 estudios encontrados, indicando el surgimiento de esta discusión.

Palabras clave: cuestión racial, enseñanza de geografía, estado del arte, Brasil. 


\section{Introdução}

O racismo é um fenômeno extremamente prejudicial à população negra e que se manifesta no espaço geográfico, segregando-a e condicionando-a a estabelecer determinadas espacialidades que se diferem das de outros grupos. O racismo brasileiro é caracterizado por ser institucional, e ocorre por meio de mecanismos velados que consolidam as desigualdades raciais e socioeconômicas. Uma das instituições em que esta forma de racismo se manifesta são as escolas.

Historicamente, no Brasil, a população negra foi excluída dos processos de ensino, e esta exclusão contribuiu para a manutenção das desigualdades existentes, como, por exemplo, o fato de os(as) negros(as) receberem menores salários que os(as) brancos(as), acessarem menos as universidades e serem a maioria dos(as) analfabetos(as) existentes.

A educação se evidencia como uma ferramenta essencial que pode auxiliar na superação do racismo por meio de uma formação que não reforce discursos e ações racistas e preconceituosas, possibilitando a construção de um imaginário positivo a respeito da população negra e incentivando os(as) estudantes negros(as) a assumirem suas identidades. Nesse sentido, a geografia é uma das disciplinas que podem proporcionar aulas que ensinem a respeito da população negra, destacando suas espacialidades, vivências e trajetórias de vida, que são diretamente relacionadas ao racismo. A partir da materialização do racismo no espaço geográfico, a população negra estabelece práticas restritas a determinados locais e possui, assim, trajetórias diferenciadas dos outros grupos sociais, sendo fundamental que as aulas de geografia abordem esta temática.

Tendo em vista esses pressupostos, evidencia-se como indispensável a discussão racial, nas aulas de geografia, sendo importante compreender como os(as) pesquisadores(as) desta ciência têm debatido esta temática no ensino de geografia, no Brasil. Assim, esta pesquisa objetiva realizar o estado da arte da questão racial no ensino de geografia, cuja problemática central se refere à pergunta: "como a questão racial tem sido discutida nos artigos publicados em periódicos nacionais, nas dissertações e nas teses de ensino de geografia?"

Para responder a este questionamento, foi realizada uma busca no Catálogo de Teses e Dissertações da Coordenação de Aperfeiçoamento de Pessoal de Nível Superior (CAPES), a respeito das dissertações e teses que discutem o ensino de geografia e a temática racial. Os artigos de periódicos foram obtidos mediante a participação em um projeto de iniciação científica da Universidade Estadual de Londrina (UEL). Após a seleção das pesquisas, estas foram analisadas por meio das técnicas de análise textual discursiva e de análise de conteúdo, que possibilitaram compreender como a questão racial tem sido discutida nessas publicações.

D 
Portanto, espera-se fomentar o debate das questões raciais no ensino de geografia e nas pesquisas acadêmicas que são produzidas por pesquisadores(as) desta ciência. Trabalhos que contemplem a questão racial se evidenciam como fundamentais num cenário em que as desigualdades raciais e socioeconômicas são, cada vez mais, intensificadas. A partir do conhecimento de como a ciência geográfica tem debatido esta temática, pode-se compreender as assertivas e as lacunas do ensino e da formação de professores(as), além de se identificar as mudanças que precisam ser realizadas, no ensino de geografia e na educação como um todo.

\section{Procedimentos metodológicos}

O referencial teórico desta pesquisa foi construído com base em autores que discutem as principais temáticas nela abordadas: a questão racial, o ensino de geografia e a educação. Priorizou-se a utilização de artigos científicos de periódicos nacionais e de livros acadêmicos.

Tendo em vista que esta pesquisa realiza um estado da arte, é fundamental que se compreenda do que se trata este conceito. As pesquisas denominadas "estado da arte" visam a mapear a produção acadêmica nas diversas áreas do conhecimento. Ferreira destaca que essas pesquisas buscam responder

[...] que aspectos e dimensões vêm sendo destacados e privilegiados em diferentes épocas e lugares, de que formas e em que condições têm sido produzidas certas dissertações de mestrado, teses de doutorado, publicações em periódicos e comunicações em anais de congresso e de seminários (FERREIRA, 2002, p. 258).

Ferreira (2002) aponta que os estados da arte permitem sistematizar um determinado campo do conhecimento, reconhecendo o que este tem produzido, quais temas tem discutido, quais as abordagens dominantes emergentes e suas lacunas. O estado da arte possui cunho epistemológico, não adotando nenhum método científico, pelo contrário, ele avalia pesquisas e os métodos utilizados nestas. Dessa forma, o estado da arte é uma pesquisa crítica acerca da produção acadêmica, refletindo sobre a natureza, as etapas, os métodos, os limites e as conclusões que são utilizados nas diversas áreas do conhecimento científico (FONSECA, SALVI, TORRES, 2014).

Para a realização do estado da arte na presente pesquisa, selecionaram-se os artigos publicados em periódicos nacionais indexados na área de Geografia e as teses e dissertações presentes no Catálogo de Teses e Dissertações da CAPES. Os artigos dos periódicos nacionais foram obtidos por meio da participação da autora deste artigo, Ana Carolina dos Santos Marques, no projeto intitulado "Pesquisas em ensino de geografia publicadas em 
periódicos nacionais: perspectivas e tendências", coordenado pelo professor Dr. Ricardo Lopes Fonseca, da Universidade Estadual de Londrina, também coautor deste artigo.

Esse projeto objetiva coletar dados a respeito das pesquisas em ensino de geografia compreendendo a série histórica de cada periódico, a fim de evidenciar onde estão os centros de pesquisa nacionais. Assim, em fevereiro de 2017, os periódicos indexados na área de geografia, de acordo com o quadriênio 2013-2016, foram investigados desde as suas primeiras publicações, em 1957. Filtraram-se apenas os periódicos nacionais e, em seguida, os que estavam on-line, para, assim, se realizar a investigação dos artigos que estavam na plataforma dos respectivos periódicos e selecionar aqueles que remetiam ao ensino de geografia. A partir disso, as publicações que se enquadram nessa temática foram novamente filtradas, sendo selecionadas apenas as que discutiam a questão racial.

Para a seleção das teses e dissertações de ensino de geografia que abordam a questão racial, foi utilizado o Catálogo de Teses e Dissertações ${ }^{1}$ da CAPES, seguindo-se os seguintes passos: cinco palavras-chave foram utilizadas para a realização da busca: África, racismo, preconceito, étnico-raciais, Lei $10.639 .{ }^{2}$ Estas palavras foram escolhidas devido ao fato de que são as que mais se repetem, nos resumos dos artigos selecionados nos periódicos nacionais mencionados no parágrafo anterior. As cinco palavras-chave foram escritas na barra de busca do catálogo (uma de cada vez), e, em seguida, selecionaram-se as opções "mestrado" e "doutorado", no campo "tipo", sendo que, no campo "área conhecimento", foi marcada a opção geografia. A partir disso, foram selecionadas as pesquisas de ensino de geografia que discutiam a questão racial. É importante destacar que diversas pesquisas se repetiram, ao longo dessa busca, uma vez que mais de uma das palavras-chave utilizadas eram discutidas nos trabalhos selecionados. Dessa forma, as pesquisas foram filtradas para que não se repetissem.

Após a obtenção dos artigos de periódicos, teses e dissertações, ocorreu a análise destes materiais por meio de seus títulos, resumos e palavras-chave, realizada com base na junção das técnicas de análise textual discursiva e de análise de conteúdo. De acordo com Sousa e Galiazzi, a análise textual discursiva proporciona a averiguação de textos por meio de categorização, reunião de unidades por semelhança e produção de metatextos:

\footnotetext{
Disponível em: https://catalogodeteses.capes.gov.br/catalogo-teses/\#!/.

2 Conforme será detalhado mais adiante, neste artigo, a Lei 10.639/03 torna obrigatório o ensino da história e da cultura afro-brasileiras de forma positiva, objetivando evidenciar as contribuições da população negra na formação do Brasil.
}

D 
Na Análise Textual Discursiva, o processo de categorizar pode ser feito por diferentes métodos, nos quais a unitarização leva à categorização. A categorização tem relação com os objetivos da pesquisa que precisam ser explicitados com clareza. Esta relação entre categorias e objetivos se estabelece no processo pela exaustividade e pela saturação das categorias, sendo estes modos de validade, confiabilidade e rigor do método. É no metatexto que se busca um afastamento do método de categorização por meio da interpretação com a qual podem ser feitas inferências à compreensão (SOUSA, GALIAZZI, 2017, p. 520).

Esses autores destacam que as categorias devem refletir as principais características dos textos no seu processo de descrição e considerar os objetivos da pesquisa. Tendo em vista as contribuições que a análise textual discursiva apresenta na interpretação de pesquisas, esta técnica pode ser complementada com a análise de conteúdo, que permite ao(a) pesquisador(a) uma leitura e interpretação aprofundadas dos significados que os atores sociais atribuem à realidade a partir de categorizações, pois

[...] pode, teoricamente, apoiar-se ou reportar-se aos elementos básicos do mecanismo clássico da comunicação: a mensagem (significação e código) e seu suporte ou canal, de uma parte; o emissor e receptor, de outra parte, como polos de inferência (comuns) propriamente ditos (BARDIN, 1977, p. 169, tradução dos autores).

De acordo com Fonseca (2015), a análise de conteúdo de Bardin é realizada em três etapas essenciais: a pré-análise, a exploração do material e o tratamento dos resultados. $\mathrm{Na}$ primeira etapa, há a ordenação dos materiais; na segunda, ocorrem o resumo dos materiais e a exploração do referencial teórico; e, por fim, na terceira etapa, têm-se a interpretação e a análise dos resultados.

Com base nas técnicas mencionadas, foi criado um quadro de análise composto da categoria em que o artigo foi classificado, do objetivo da pesquisa, das palavras-chave, do tipo de trabalho (artigo, dissertação ou tese) e da frequência relativa das palavras-chave e metatexto, que apresenta a discussão dos dados obtidos. No entanto, antes da apresentação dos resultados desta pesquisa, é fundamental que se compreendam a questão racial, a educação brasileira destinada aos(as) negros(as), a importância da escola na superação do racismo e a relação da geografia com esta temática.

\section{O estado da arte das pesquisas de ensino de geografia que discutem a questão racial: abordagem quantitativa}

A população negra foi, historicamente, excluída dos âmbitos da sociedade, criandose um cenário consolidado de desigualdades raciais e sociais no Brasil, e a escola foi uma das instituições que contribuíram para a manutenção destas desigualdades. Portanto, nesta 
pesquisa, é preciso não apenas indicar-se o estado da arte, mas também propor formas de se contemplar a questão racial nos processos de ensino e de aprendizagem da geografia a fim de se contribuir para uma educação antirracista.

Nesse sentido, é importante entender se o ensino de geografia tem discutido a questão racial e de que forma isto acontece. Uma das formas de se aferir se essas discussões têm sido realizadas é por meio das pesquisas científicas que são elaboradas por pesquisadores(as) de todo o Brasil. Dessa forma, as teses, as dissertações e os artigos científicos produzidos acerca dessa temática, ao longo dos anos, foram identificados e categorizados.

Em relação aos artigos científicos de periódicos nacionais, das edições de 187 periódicos indexados em geografia, foram analisados os trabalhos publicados até o ano de 2016. Estes periódicos possuíam o total de 60.217 artigos, em geral, sendo que 1.458 artigos eram sobre o ensino de geografia, dos quais apenas 12 pesquisas abordavam a questão racial, o que já apontava para a escassez do debate no ensino desta disciplina.

O Quadro 1 apresenta o estado da arte das teses e dissertações que discutem a questão racial no ensino de geografia no Brasil.

\section{Quadro 1 - Estado da arte das teses e dissertações que discutem a questão racial no ensino de geografia.}

\begin{tabular}{c|c|c|c|c|c|c}
\multirow{2}{*}{$\begin{array}{c}\text { Palavras- } \\
\text { chave }\end{array}$} & \multicolumn{3}{c|}{$\begin{array}{c}\text { DADOS REFERENTES ÀS } \\
\text { DISSERTAÇÖES }\end{array}$} & \multicolumn{2}{c}{ DADOS REFERENTES ÀS TESES } \\
\cline { 2 - 7 } & $\begin{array}{c}\text { Total } \\
\text { geral }\end{array}$ & $\begin{array}{c}\text { Em } \\
\text { geografia }\end{array}$ & $\begin{array}{c}\text { Em ensino de } \\
\text { geografia }\end{array}$ & $\begin{array}{c}\text { Total } \\
\text { geral }\end{array}$ & $\begin{array}{c}\text { Em } \\
\text { geografia }\end{array}$ & $\begin{array}{c}\text { Em } \\
\text { ensino de } \\
\text { geografia }\end{array}$ \\
\hline África & 2.442 & 46 & 4 & 1.219 & 24 & 1 \\
\hline Preconceito & 2.750 & 26 & 2 & 677 & 7 & 0 \\
\hline Racismo & 1.517 & 11 & 6 & 520 & 7 & 0 \\
\hline Étnico-raciais & 3.170 & 52 & 7 & 1.036 & 23 & 1 \\
\hline $10.639 / 03$ & 4.190 & 54 & 11 & 1.304 & 9 & 1 \\
\hline
\end{tabular}

Organizado pelos autores. 
Com base no Quadro 1, é evidente que o número de dissertações é superior - mais que o dobro - ao de teses. Pensando a partir do total de teses e dissertações, a palavrachave "10.639/03" é a mais recorrente nas pesquisas, e "racismo" é a menos recorrente. Analisando-se o número de teses e dissertações de geografia que contêm estas palavras, o quadro se repete em relação à recorrência.

As pesquisas que possuem as palavras-chave "África", "racismo" e "10.639/03", definitivamente, discutem a questão racial. Porém, é importante considerar que não são todos os trabalhos que contêm as palavras "preconceito" e "étnicos-raciais" que discutem essa temática, tendo em vista que alguns abordam o preconceito contra a mulher, contra as pessoas de diversas orientações sexuais e identidades de gênero (os LGBTQIA+) e outros que versam a respeito das relações étnico-raciais priorizando os povos indígenas, por exemplo.

O número de teses em ensino de geografia que discutem a questão racial é baixo e o número de dissertações também não é elevado, considerando-se a totalidade das pesquisas em geral e em geografia que abordam a temática do racismo. Tendo em vista que algumas pesquisas se repetem de acordo com as palavras-chave, o número de trabalhos apresentados no Quadro 1 foi filtrado, e o panorama de pesquisas em ensino de geografia que discutem a questão racial é representado pelo total de 15 dissertações e duas teses. Somadas estas ao número de artigos científicos, obtém-se o total de 29 pesquisas.

O baixo número de pesquisas encontradas revela a escassez da discussão racial no ensino de geografia. Esta escassez acontece não apenas na geografia, mas na ciência, como um todo, pois há um silenciamento da população negra e dos assuntos a ela relacionados. Este cenário é resultante, entre outros fatores, da estrutura colonial do poder, que, como aponta Quijano (1992, p. 12, tradução dos autores), produz “[...] discriminações sociais que posteriormente foram codificadas como "raciais", étnicas, "antropológicas" ou "nacionais", de acordo com os momentos, os agentes e as populações envolvidas". Predominou um discurso eurocêntrico, na ciência, que silenciou o conhecimento dos sujeitos não hegemônicos. A insurgência de pesquisas que discutem sujeitos discriminados historicamente passa a aumentar a partir de ações como a elaboração de políticas públicas que os contemplem, exemplificadas pela criação da Lei 10.639/03.

A Figura 1 apresenta o mapa com a localização das universidades às quais os(as) autores(as) selecionados para o nosso estudo estão vinculados(as) e a quantidade de pesquisas produzidas por instituição. 
Figura 1 - Localização das instituições dos(as) pesquisadores(as) selecionados(as) e quantidade de pesquisas produzidas.

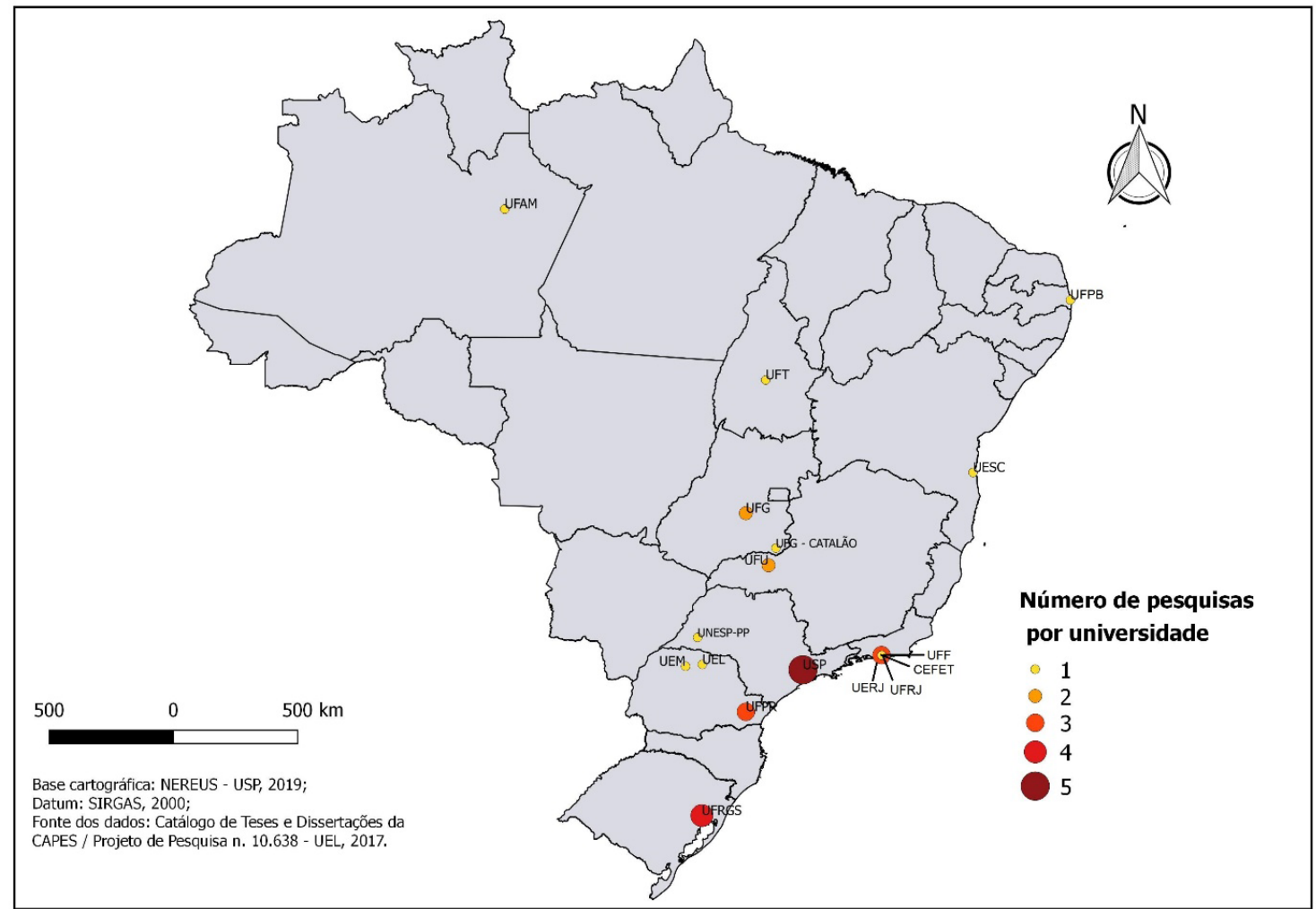

Elaborada pelos autores.

Faz-se importante destacar, devido à sobreposição de dados, que, no estado do Rio de Janeiro, há quatro instituições que possuem pesquisadores(as) discutindo o ensino de geografia e a questão racial: a Universidade do Estado do Rio de Janeiro (UERJ), com três pesquisas; a Universidade Federal do Rio de Janeiro (UFRJ), com uma pesquisa; a Universidade Federal Fluminense (UFF), com uma pesquisa; e o Centro Federal de Educação Tecnológica Celso Suckow da Fonseca, com uma pesquisa.

Por meio das informações obtidas no mapa acima, se torna evidente que a instituição com o maior número de pesquisas que discutem o ensino de geografia e a questão racial é a USP, com cinco publicações, seguida da Universidade Federal do Rio Grande do Sul (UFRGS), com quatro pesquisas. Nota-se, também, que as pesquisas se concentram em instituições do Sul e do Sudeste do Brasil. Em suma, esses dados demonstram que há poucos(as) pesquisadores(as) que discutem a questão racial no ensino de geografia, o que evidencia a necessidade de maior debate sobre este tema, tendo em vista a sua relevância na sociedade atual, bem como as contribuições que a ciência geográfica oferece e que podem auxiliar na superação do racismo.

D

D

D Revista da Associação Nacional de Pós-graduação e Pesquisa em Geografia (Anpege).

D D

p.86-122, V.15, n.28, set./dez. 2019. 
À medida que mais publicações a respeito dessa temática forem realizadas, maior será a discussão e os(as) professores(as) terão acesso a mais pesquisas que podem potencializar suas práticas pedagógicas a fim de se superar a manutenção das desigualdades raciais que são propagadas pela sociedade e pela própria escola. Na Figura 2, temos os anos em que as pesquisas selecionadas para o nosso estudo foram produzidas.

Figura 2: Anos em que as pesquisas em ensino de geografia que discutem a questão racial foram produzidas.

\section{Ano em que as pesquisas em ensino de geografia que discutem a questão racial foram produzidas}

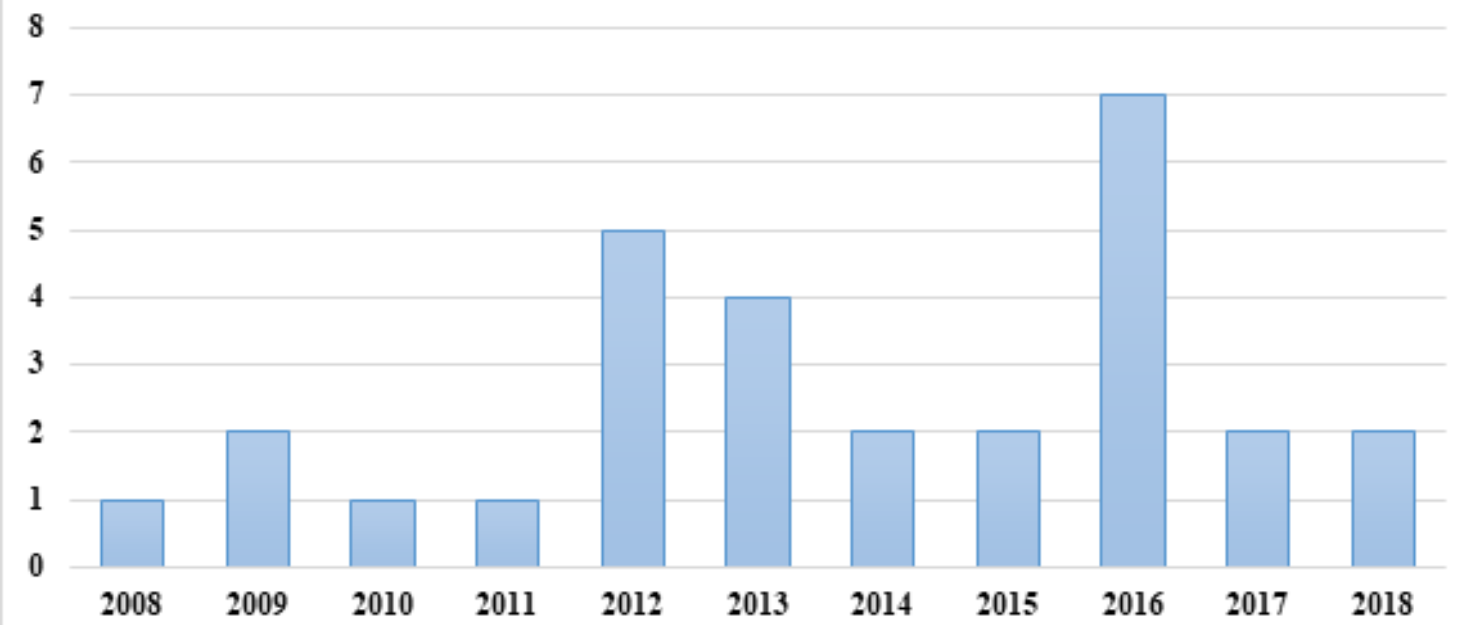

Organizado pelos autores.

Conforme se vê na Figura 2, as pesquisas a respeito da questão racial no ensino de geografia surgem apenas em 2008, tendo o seu ápice em 2012 (com cinco pesquisas) e em 2016 (com sete pesquisas). Este cenário reflete a conjuntura brasileira a partir da criação de políticas públicas que contemplam a população negra, em especial a Lei 10.639/03 e o Estatuto da Igualdade Racial (2010), e, portanto, acreditamos que o debate relacionado a esta população tende a aumentar, tendo em vista a importância da aplicação destas leis e das demais discussões que a cercam.

Santos (2011) aponta que a Lei 10.639/03 reposiciona o(a) negro(a) e as relações raciais na educação, transformando o silenciamento em denúncia e problematização, e chama a atenção para como os conhecimentos (aparentemente neutros) contribuem para a reprodução de estereótipos e para o racismo. 
Dessa forma, justifica-se a importância do estado da arte proposto nesta pesquisa, no sentido de se evidenciar o baixo quantitativo de publicações sobre a questão racial no ensino de geografia, de modo a se alertar para a emergência dos debates social e científico desta temática. Além disso, o estado da arte nos proporciona buscar nos(as) autores(as) que já trabalham com esta abordagem possibilidades de avançar nesse campo.

Nesse sentido, a partir do panorama quantitativo apresentado, considera-se necessária uma discussão teórica acerca de elementos conceituais que permitam um entendimento da análise qualitativa, que se encontra após o referencial teórico.

\section{A questão racial}

A questão racial pode ser identificada como o debate dos temas relacionados ao racismo e à população negra, ${ }^{3}$ como, por exemplo, o preconceito, o estereótipo, a discriminação racial, a violência, a vulnerabilidade social, a exclusão social e a desigualdade racial. As discussões relacionadas a estas temáticas se destacam como imprescindíveis na medida em que a população negra brasileira vivencia contextos permeados por desigualdades raciais e socioeconômicas.

O racismo é uma ideologia que acredita na hierarquia entre os grupos humanos, não sendo uma prática recente, no Brasil e no mundo. Ela surgiu no século XV, foi se consolidando, ao longo da história, e ganhando, em alguns momentos, justificativas científicas para a inferiorização dos grupos discriminados - no caso desta pesquisa, dos(as) negros(as). Como aponta Sant'Ana (2005), as marcas do racismo permanecem na sociedade, até os dias presentes, sobrevivendo a gerações, e, muitas vezes, ganhando força por meio de discursos e ações discriminatórias.

De acordo com Quijano (2005), na América, a ideia de raça foi utilizada como forma de legitimar as relações de dominação impostas pela conquista. Difundiu-se uma perspectiva eurocêntrica do conhecimento, e, por meio dela, ocorreu uma naturalização e uma legitimação das relações coloniais de dominação entre os povos europeus e os não europeus: “[...] os povos conquistados e dominados foram postos numa situação natural de inferioridade, e consequentemente também seus traços fenotípicos, bem como suas descobertas mentais e culturais" (QUIJANO, 2005, p. 117-118). Em suma, a raça foi utilizada como forma de classificação social.

De acordo com a classificação aplicada pelo IBGE, a população negra corresponde à soma das pessoas que se autodeclaram pretas e pardas.

D 
No Brasil, o racismo está associado à escravidão da população negra, e se consolidou após a abolição dos escravos, em 1888, por meio de mecanismos institucionais que foram utilizados para segregar este grupo. As desigualdades socioeconômicas e raciais foram fortalecidas à medida que os(as) negros(as) foram libertos(as), sem garantias de nenhum mecanismo para a sua inclusão na sociedade, sendo obrigados(as) a buscar moradias nas periferias das cidades, desprovidas de infraestrutura, e a aceitar trabalhos subjugados ou, então, a sobreviver por meio do mercado de trabalho informal.

$\mathrm{Na}$ realidade brasileira, foi criada uma série de mecanismos institucionais que consolidam o racismo e colocam a população negra em posições inferiores, tornando extremamente difícil a sua saída desta condição e a melhoria de suas condições de vida. Assim, esse racismo ocorre de uma forma velada, não por meio de discriminações explícitas, mas por meio de ações em instituições do mercado de trabalho, da educação e do governo, ou seja, é o racismo institucional incidindo sobre a pessoa negra.

Wieviorka (2007) aponta que o racismo institucional mantém os(as) negros(as) em situação de inferioridade por meio de dispositivos não percebidos socialmente. Este racismo está presente no funcionamento da sociedade e nas situações rotineiras, manifestandose de maneira camuflada, na forma de dominação e de inferiorização dos negros, sem que ninguém tenha a necessidade de teorizá-lo ou justificá-lo com base na ciência. É um racismo que ocorre sem atores - que, na realidade, são atores ocultos, que não se revelam à população -, em que o conjunto dos que dominam é exterior à sua prática e, ainda assim, se beneficia dela.

O racismo institucional ocorre nas estruturas da sociedade e em suas instituições, como no mercado de trabalho e nas empresas privadas, nos órgãos públicos governamentais, nas igrejas, nas universidades e nas escolas. Nesse sentido, a população negra é excluída com base em seus aspectos corporais, possuindo menos oportunidades e direitos sociais. Os(as) negros(as) não podem mudar suas características corporais, e, em função delas, ao longo de suas vidas, sofrem diversas injustiças que determinam suas trajetórias. A sociedade brasileira é induzida a pensar que vivemos em uma democracia racial e que, na prática, todos(as) possuímos os mesmos direitos.

Acredita-se que as desigualdades raciais são motivadas apenas pela questão econômica, e este mito é fortemente sustentado pela bandeira da falsa democracia racial, que defende que a população brasileira vive em um sistema racial desprovido de barreiras legais ou institucionais para a igualdade racial (DOMINGUES, 2004). Assim, como destaca Silva (2000, p. 111), “[...] está arraigada no pensamento social brasileiro a ideia de que o pobre 
é o único responsável por sua posição social, assim como o negro à pobreza, remetendo ao injustiçado a responsabilidade pela própria posição". Tal concepção indica a presença de ideais baseados na meritocracia.

Faz-se fundamental a compreensão de que as desigualdades socioeconômicas da população negra estão diretamente ligadas à raça ${ }^{4}$ e à classe social. Se, geralmente, os(as) negros(as) se concentram entre as classes populares da sociedade, isto não é uma opção adotada por esta população, mas, sim, o resultado de um processo muito amplo relacionado ao racismo. Como já foi ressaltado, o racismo está institucionalizado em diferentes âmbitos da sociedade, e, como um fenômeno, ele se materializa no espaço geográfico à medida que a população negra é destinada a vivenciar determinados territórios diferenciados de outros grupos, como a população branca de alto poder aquisitivo.

Nesse sentido, a geografia pode dar contribuições para o entendimento da questão racial e de como esta se manifesta no espaço geográfico, oferecendo questionamentos como: quais os lugares em que a população negra brasileira se concentra, e por que isto ocorre; em quais condições esta população vive?; por que recebe os menores salários, e qual é o impacto disto em sua qualidade de vida?; quais são os interesses que permeiam a organização da sociedade, baseados na classe, na raça e no gênero, e que segregam a população negra? É fundamental mostrar que a população negra está presente, no Brasil, que contribui para o desenvolvimento deste país, que resiste a todo o racismo e à segregação que lhe são impostos e que é alvo de uma série de condicionantes que a marginaliza e que acentuam as desigualdades socioeconômicas.

Dessa forma, a geografia se evidencia como uma ciência e uma disciplina - pensandose no âmbito educacional - que possui o potencial de ensinar aos(às) estudantes que os objetos e os sujeitos não ocupam uma posição no espaço geográfico por coincidência, pois há uma série de intencionalidades que permeiam a sua organização. A geografia, como disciplina, é ensinada nas escolas - e a educação é um instrumento que pode auxiliar nesses debates, contribuindo para a superação do racismo -, porém, é importante entender que, assim como outras instituições, as escolas também disseminam práticas que aprofundam a exclusão da população negra, sendo este o resultado de um processo histórico.

\footnotetext{
4 O termo raça passou por um processo de ressignificação e politização, sendo identificado como uma construção social estrutural e estruturante para se compreender o complexo quadro de discriminações e desigualdades, no Brasil (GOMES, 2012).
}

D 


\section{A exclusão histórica da população negra na educação brasileira e a importância da escola na superação do racismo}

A desigualdade social e racial está fortemente materializada, no sistema de ensino brasileiro. Os dados do IBGE de 2016 são alarmantes, para a desigualdade racial presente na educação. Segundo este levantamento, a taxa de analfabetismo era de 4,2\%, entre brancos, e de $9,9 \%$, entre negros. Do total de 1.835 crianças, entre 5 e 7 anos, que trabalhavam, $35,8 \%$ eram brancas e 63,8\% eram negras (IBGE, 2017b).

Ainda em 2016, das pessoas que não tinham instrução, 7,3\% eram brancas e 14,7\% eram negras. A taxa de escolarização entre brancos era de $37,4 \%$, sendo superior à de negros, que equivalia a 29,4\%. A média de anos de estudos, para as pessoas brancas, era de 9 anos, e de 7,1 anos, para as negras. Por fim, das pessoas com 25 anos de idade ou mais que possuíam ensino superior, 22,2\% eram brancas e 8,8\% eram negras (IBGE, 2017b).

Evidencia-se que a população negra não está equiparada à população branca, no ensino brasileiro, e este problema é decorrente do fato de que, historicamente, os(as) negros(as) foram silenciados e subjugados por uma estrutura colonial de poder e de dominação, tendo seus direitos (como, por exemplo, uma educação de qualidade) negados. Para se compreender este cenário, é importante que se entenda como, ao longo da história, os negros foram excluídos do processo de ensino, acumulando desigualdades sociais e raciais.

Inicialmente, é importante destacar, como aponta Cruz (2005), que, na história da educação brasileira, são escassas as pesquisas que contemplem as trajetórias educacionais e escolares dos negros. Esta problemática revela, segundo a referida autora, que não são os povos negros que não têm história, mas, sim, que as fontes históricas, ao invés de serem conservadas, foram destruídas nos processos de dominação.

Negros(as), assim como indígenas, eram considerados um entrave à modernidade do país, e, portanto, pouca atenção foi destinada a esses grupos. Segundo Gonçalves e Silva (2000), no período do regime escravocrata, os escravos eram impedidos de aprender a ler e a escrever e de cursar as escolas existentes, sendo que apenas os escravos de fazendas comandadas por padres jesuítas tinham o direito à instrução, mas a um alto preço, pois a educação jesuíta os aculturava, moldando o seu comportamento social e lhes ensinando somente a visão cristã do mundo. 
No que tange ao século XIX, algumas políticas foram criadas pelo Estado, porém, executadas de forma incorreta, não alterando a estrutura marcada pela desigualdade. No dia 13 de maio de 1888, a Lei Áurea foi assinada e se instituiu a abolição da escravidão, entretanto, a extinção do trabalho escravo foi um processo gradual, na segunda metade do século XIX, não se encerrando imediatamente com a assinatura desta lei. Após a abolição, a vida da população negra foi marcada pelo abandono, e nenhum tipo de política pública foi criado para a inserção dos negros na sociedade, consolidando-se a desigualdade social e racial, no Brasil. Além disso, o início do século XX foi caracterizado pela urbanização e modernização das cidades, sendo que, neste processo, os(as) negros(as) foram destinados aos trabalhos rejeitados pela população branca e a morar nas áreas desprovidas de infraestrutura e de instituições escolares de qualidade, aumentando a vulnerabilidade a que este grupo estava exposto.

O passado escravista do Brasil se refletiu diretamente nas experiências educacionais da população negra, no início do século XX. Crianças negras, por exemplo, foram afastadas dos bancos escolares e levadas a atividades remuneradas para auxiliarem na renda familiar. Nesse período, a educação dos homens negros - quando acontecia - se dava na idade adulta, em sua maioria, e as mulheres eram encaminhadas para orfanatos, onde recebiam preparo para o trabalho como empregadas domésticas ou costureiras, o que também as afastava da educação formal. Muitas famílias abastadas “adotavam” estas mulheres para que fossem empregadas domésticas não remuneradas em suas casas (GONÇALVES, SILVA, 2000). Em suma, a necessidade de trabalhar era um dos fatores que afastavam a população negra das escolas brasileiras.

A partir dos anos de 1920, reformas educacionais começaram a ser realizadas, e as crianças negras passaram a frequentar as escolas, porém, de uma maneira extremamente excludente, tendo em vista que essa educação foi marcada pelas teorias eugenistas, que objetivavam branquear a população, expondo as crianças negras a uma série de procedimentos que internalizavam nelas o sentimento de inferioridade.

De acordo com D’avila (2006), a eugenia é a prática de aperfeiçoar física e mentalmente a raça humana por meio da manipulação dos traços hereditários, tendo sido defendida por médicos, cientistas e cientistas sociais. Na primeira metade do século XX, a população negra era tida como símbolo da degeneração da sociedade brasileira. D’avila (2006) aponta que a escola se tornou um laboratório eugênico que buscava o branqueamento comportamental. Acreditava-se que a população negra, principalmente a pobre, era degenerada e que poderia ser embranquecida, por meio da inserção de cultura, de práticas de saúde e de higiene e do

D

D D Revista da Associação Nacional de Pós-graduação e Pesquisa em Geografia (Anpege).

D D

p.86-122, V.15, n.28, set./dez. 2019. 
ensinamento de comportamentos considerados adequados, assim, a educação foi uma das formas para se alcançar este objetivo. Como destaca D’avila (2006, p. 24), transformaramse as escolas públicas em “[...] espaços em que séculos de supremacismo branco-europeu foram reescritos nas linguagens da ciência, do mérito e da modernidade".

Nesse cenário em que o Estado foi falho com a população negra, emergiram os primeiros movimentos de protesto de grupos de negros(as) que lutavam contra a subordinação social, como, por exemplo, a Frente Negra Brasileira. Gonçalves e Silva (2000) ressaltam que os movimentos negros passaram a oferecer escolas visando a alfabetizar adultos(as) e a promover uma formação mais completa para as crianças negras. Dessa forma, os principais avanços e conquistas relacionados à educação da população negra foram obtidos por meio da luta desses movimentos que proporcionavam a formação da coletividade, se destacando por seus cunhos políticos, culturais e educacionais. Essas organizações se configuraram como ambientes educativos:

\begin{abstract}
A luta das camadas negras pela sua inclusão no processo de escolarização oficial, as lições repassadas na imprensa negra sobre "boas maneiras", o estímulo ao desenvolvimento de práticas culturais de origem africana, a luta pela inclusão de temas específicos dos afrodescendentes na escola comum, a luta em torno de aglutinar os afrodescendentes em uma identidade negra positiva, os cursos de atualização, os cursos de alfabetização, os cursos de música, de inglês, de educação física, de artes, corte e costura, as palestras, os seminários, são exemplos de práticas vinculadas à ação organizada dos negros que caracterizam uma história da educação que, embora ausente nos relatos oficiais da história da educação brasileira, evidencia que, mesmo à margem da cidadania, os negros acompanharam os processos de compactação da nação brasileira e neles exerceram influência (CRUZ, 2005, p. 11).
\end{abstract}

Os movimentos sociais negros objetivavam combater a discriminação racial e criar mecanismos de valorização da raça negra. Neste âmbito, o direito à educação se tornou uma de suas principais bandeiras. A educação sempre foi vista como uma forma de ascensão da população negra e de superação do racismo, possibilitando a sua equiparação com os brancos e o acesso a oportunidades iguais no mercado de trabalho (GONÇALVES, SILVA, 2000).

As questões relacionadas à educação da população negra começaram a ser realmente debatidas pelo público em geral apenas a partir dos anos de 1980, com a criação do Movimento Negro Unificado, ${ }^{5}$ que, desde o seu primeiro manifesto, criou desdobramentos, como a proliferação de diversas entidades negras em todo o país, colocando a educação

O Movimento Negro Unificado (MNU) foi criado em 1978, e corresponde à luta da população negra objetivando resolver seus problemas, na sociedade abrangente, que, em sua maioria, são provenientes dos preconceitos e das discriminações raciais que os marginalizam no mercado de trabalho e no sistema educacional, político, social e cultural. Nesse debate, os termos raça e identidade racial são elementos não só de mobilização, mas também de mediação das reivindicações políticas (DOMINGUES, 2007). 
como uma prioridade de sua luta. Uma das principais conquistas deste movimento foi a implementação da política de cotas, que proporcionou à população negra adentrar na universidade e ter maiores chances de mudar suas condições de vida e de sua família, sendo este um grande avanço na história da educação dos negros. Além das ações afirmativas, nos anos 2000, um importante passo na busca da superação do racismo foi a Lei 10.639/03, que discutiremos no próximo tópico.

Em suma, constatamos que as oportunidades no acesso a uma educação de qualidade foram escassas e desiguais, para a população negra, aprofundando as desigualdades, exclusões e segregações que vivenciam cotidianamente. Nas últimas décadas, alguns avanços foram conquistados, por meio de reivindicação e luta das entidades negras, porém, é importante ter em mente que diversas outras políticas públicas (na educação e na sociedade, como um todo) precisam ser criadas, além de que a própria população não negra e não afrodescendente precisa reconhecer seus privilégios históricos e contribuir na busca por equidade, por meio de suas ações e, principalmente, por meio da não disseminação de ideias racistas. Neste contexto que evidencia a urgência da superação do racismo, a escola é uma das instituições que têm muito a contribuir nesta luta.

A escola foi - e, em parte, ainda é - uma instituição que, historicamente, fortaleceu o racismo, contribuindo para a perpetuação das desigualdades raciais e socioeconômicas. Ela é um dos espaços que mais interferem na construção da identidade negra dos(as) estudantes: "O olhar lançado sobre o negro e sua cultura, no interior da escola, tanto pode valorizar identidades e diferenças, quanto pode estigmatizá-las, discriminá-las, segregá-las e até mesmo negá-las" (GOMES, 2002, p. 39). Nesse sentido, é fundamental que a escola valorize a cultura negra e proporcione aos(as) estudantes negros(as) o sentimento de orgulho de sua origem, da história de seu povo e de sua raça. A superação do racismo se mostra imprescindível, e a comunidade escolar, como um todo, precisa ter o compromisso pedagógico e social de trabalhar as questões raciais de forma positiva.

Gomes (2002) aponta ações que são reproduzidas pela escola e consolidam esta instituição como sendo desigual e excludente:

[...] veremos que a presença significativa de alunos e alunas negros nas ditas "classes especiais" representa um reflexo da desigualdade racial que assola a sociedade brasileira e impregna a estrutura de suas diversas instituições. Ou seja, a própria estrutura da escola brasileira, do modo como é pensada e realizada, exclui o aluno e a aluna negros e pobres. Essa exclusão concretizase de maneiras diversas: por meio da forma como alunos e alunas negros são tratados; pela ausência ou pela presença superficial da discussão da questão racial no interior da escola; pela não-existência dessa discussão nos cursos e

D 
centros de formação de professores/as; pela baixa expectativa dos professores/ as em relação a esse aluno/a; pela desconsideração de que o tempo de trabalho já faz parte da vida do aluno/a negro/a e pobre; pela exigência de ritmos médios de aprendizagem, que elegem um padrão ideal de aluno a ser seguido por todos a partir de critérios ditados pela classe média branca, pelo mercado e pelo vestibular, sem considerar a produção individual do aluno e da aluna negra, assim como de alunos de outros segmentos étnicos/raciais (GOMES, 2002, p. 41).

Há, assim, uma série de estigmas que são produzidos e reproduzidos a respeito dos(as) estudantes negros(as) e da população negra que os(as) fazem se sentir menos capazes e, até mesmo, fracassados(as). A população negra e sua vivência são abordadas nas escolas, porém, majoritariamente associadas à escravidão. Raramente, é dada ênfase às inúmeras contribuições dos(as) negros(as), e os(as) estudantes passam a vê-los(as) somente como escravos(as), considerando que o racismo ficou no passado e que, na sociedade brasileira, todos(as) são tratados(as) de forma igual.

Os(as) professores(as) precisam desnaturalizar as desigualdades raciais e sociais e ensinar aos(as) estudantes que o atual contexto racial brasileiro é reflexo de um processo histórico, político, econômico, social e cultural que consolidou as diferenças entre os(as) negros(as) e o restante da população, aprofundou o racismo e institucionalizou diversos mecanismos que impediram os(as) negros(as) de ascenderem social e economicamente. Faz-se fundamental que a escola discuta o racismo e as contribuições que a população negra legou à construção da sociedade brasileira - contribuição esta realizada com muito sofrimento, mortes, sangue e escravização, mas, acima de tudo, com luta e resistência.

Os(as) estudantes precisam conhecer o racismo estrutural que permeia a sociedade brasileira para que não reproduzam práticas e discursos discriminatórios, consolidando ainda mais o racismo, o preconceito e a discriminação racial. Além disso, ao trabalhar as contribuições da população negra, o(a) estudante negro(a) reconhece as realizações de seus antepassados, a sua força e importância, orgulhando-se de ser negro(a). Para tanto, é imprescindível que os(as) professores(as) conheçam a questão racial e saibam como abordála em sala de aula, tarefa que exige conhecimento, respeito, interesse e empatia. A questão racial deve ser uma temática abordada no processo de formação de professores(as), e o conhecimento histórico e conceitual deste tema “[...] poderia ajudar os(as) educadores(as) a compreenderem a especificidade do racismo brasileiro e auxiliá-los a identificar o que é uma prática racista e quando esta acontece no interior da escola” (GOMES, 2005, p. 148).

Glass (2012) destaca que a educação deve ter um comprometimento sério e estratégico de transformar vidas e a sociedade em geral, eliminando o racismo. A finalidade da educação 
racialmente crítica e antirracista não é identificar e indicar o racismo, mas permitir que cada pessoa assuma a responsabilidade para a transformação da ordem racial. Seu objetivo, de acordo com esse autor, é construir uma comunidade dentro da qual o diálogo e a ação racialmente crítica e antirracista prosperem, porque tais atos não se referem a culpa, mas a estabelecer o respeito e a oportunidade a uma democracia justa. É necessário ser responsável e incorporar uma resposta sincera às dificuldades dos(as) menos afortunados(as) devido às tradições da supremacia racial e também incluir um esforço comprometido para mudar tudo o que estiver ao seu alcance.

Dessa forma, uma das ações criadas, a partir da pressão do movimento negro, para auxiliar na ressignificação das práticas pedagógicas nas escolas e nas discussões que contemplem negros(as) em todos os sentidos foi a Lei 10.639/03, que torna obrigatório o ensino da história e da cultura afro-brasileiras (BRASIL, 2003). Desse modo, todas as disciplinas escolares devem adequar seus currículos à Lei 10.639/03, objetivando promover conteúdos relacionados à população negra de forma positiva. É fundamental apontar que o povo negro está presente na sociedade e que é alvo de práticas racistas cotidianamente, que resiste à exclusão social e busca condições de equidade em oportunidades para a melhoria de sua vida e a superação do racismo.

A Lei 10.639/03 representa um marco na busca por uma educação antirracista, pois rompe com uma série de mecanismos discriminatórios que foram promovidos pela escola, ao longo da história:

\begin{abstract}
A oficialização da temática referente às populações negras na escola através da lei acarreta a discussão de assuntos que foram silenciados durante muito tempo, na sociedade brasileira, sempre com o véu de que "aqui não há racismo", argumento que apenas esconde a real formação do povo brasileiro e a importância de diferentes grupos étnico-raciais para a formação da história e cultura do Brasil. Então, estudar a história africana e afro-brasileira não possui o intuito de mudar o foco eurocêntrico para outro africano, mas de ampliar as discussões para a diversidade cultural, racial, social e econômica existente em nosso país (OLIVEIRA, CUNHA JÚNIOR, 2012, p. 4).
\end{abstract}

Desse modo, é evidente a necessidade de discussão da diversidade cultural, racial, social e econômica em sala de aula. No que diz respeito à questão racial, é importante indicar por que o racismo existe, como foi criado, por quem e para quem. $\mathrm{O}$ (a) professor(a) pode apontar que esta ideologia é antiga e que foi criada e consolidada devido à influência de sujeitos que a utilizaram a seu favor, buscando obter lucros e domínios por meio da inferiorização, aculturação e morte de muitos(as) negros(as). Os(as) estudantes precisam saber quais são os interesses que permeiam o racismo e quem é beneficiado com esta

D

D D Revista da Associação Nacional de Pós-graduação e Pesquisa em Geografia (Anpege).

D D

p.86-122, V.15, n.28, set./dez. 2019. 
ideologia, para compreenderem que ela não é válida, que foi e ainda é extremamente perversa para a população negra.

Nesse sentido, a geografia é uma das disciplinas com grande potencial de contribuir para o entendimento da questão racial, tendo em vista que o racismo é um fenômeno que se manifesta espacialmente. É importante que o ensino dessa ciência aponte as espacialidades das desigualdades raciais e socioeconômicas que restringem a população negra geralmente às periferias da cidade, evidenciando-se que a disposição dos objetos e sujeitos não é fruto de uma simples coincidência. A partir disso, os(as) estudantes podem compreender que a discriminação racial existe e que não é uma escolha da população negra, mas, sim, a consequência de um processo histórico. Este exercício pode abrir espaço para um ensino ressignificado e positivo para os(as) estudantes em geral, que poderão aprender acerca das contribuições da população negra na construção do país.

\section{As potencialidades do ensino de geografia na discussão da questão racial}

O ensino de geografia possui contribuições no que diz respeito à abordagem da questão racial, porém, antes de refletirmos acerca desta temática, é fundamental compreendermos a função da ciência geográfica nas escolas, tendo em vista que, a partir do momento em que ela se torna significativa aos(as) estudantes, eles(as) poderão compreender a questão racial por meio das espacialidades.

Cavalcanti (1998) ressalta que a função da geografia está ligada à capacidade que os sujeitos precisam ter de ler e analisar criticamente o espaço geográfico, compreendendo as intenções, as tensões e as contradições presentes, e qual o seu papel na prática cotidiana, possibilitando, dessa forma, uma inserção efetiva e reflexiva neste espaço. É importante que os estudantes conheçam o mundo em que vivem, se localizem e se representem linguística e graficamente. Para Cavalcanti (1988, p. 128), a função mais importante da geografia é "formar uma consciência espacial, um raciocínio geográfico". Esta autora prossegue, afirmando que "e formar uma consciência espacial é mais do que conhecer e localizar, é analisar, é sentir, é compreender a espacialidade das práticas sociais para poder intervir nelas a partir de convicções, elevando a prática cotidiana, acima das ações particulares, ao nível do humano genérico" (CAVALCANTI, 1998, p. 128).

O cotidiano dos(as) estudantes é repleto de geografia, e, ao compreender os seus conteúdos, o olhar do(a) estudante para o espaço vivenciado nunca mais será o mesmo. No caminho até a sua escola, por exemplo, será possível identificar diversos conteúdos 
apreendidos em sala de aula. De acordo com Damiani (2006), por meio da formação de uma consciência espacial, a partir do ensino dos conteúdos geográficos, o(a) estudante poderá desvendar os significados do espaço geográfico, se reconhecer como cidadão(ã) e sujeito social que se apropria e produz o espaço, possuindo discernimento das experiências sociais e individuais e, consequentemente, potencializando-as.

Portanto, a geografia proporciona ao estudante exercer a sua cidadania e criticidade, atuando efetivamente sobre a realidade a partir do momento em que a conhece e se reconhece nela como sujeito social. Ele(a) tem a possibilidade de construir conscientemente o espaço geográfico e perceber todos os interesses refletidos em suas formas, conteúdos e dinâmicas. Dessa forma, a geografia possui diversas contribuições para a formação dos(as) estudantes, possibilitando a compreensão do espaço geográfico, a criação de uma consciência espacial e de um raciocínio geográfico. É fundamental ${ }_{2}$ então, que essa disciplina trabalhe temáticas atuais e importantes para o entendimento da atual configuração socioespacial da sociedade. A questão racial é uma destas temáticas.

Segundo Silva (2000), a raça e a classe social dos indivíduos, juntamente com o racismo, são fatores que classificam a população socialmente, interferindo em suas trajetórias de vida e em sua inserção na sociedade. Estes fatores determinam onde essa população irá morar, a quais espaços da cidade terão acesso e como as suas relações sociais acontecerão. Portanto, a questão racial é um fenômeno geográfico na medida em que se manifesta espacialmente, organizando o espaço geográfico com base nas ideologias do grupo dominante.

Santos (2010) salienta que a geografia serve para a construção de referenciais posicionais dos sujeitos no mundo:

[...] isto torna a leitura espacial das relações raciais uma tarefa importante, pois a raça é um princípio social de classificação de indivíduos e grupos, construído artificialmente para o ordenamento de relações de hierarquias e poder. Enquanto tal, ela regula comportamentos e relações, interfere nas trajetórias de indivíduos e na inserção social de grupos, sendo então um fator crucial na constituição da nossa estrutura social e espacial (SANTOS, 2010, p. 143-144).

Apesar de o ensino das relações raciais ser fundamental nas aulas de geografia, Anjos (2005) aponta que, geralmente, é dada pouca atenção ao continente africano, pois se priorizam os continentes europeu e americano. Porém, o território africano se caracteriza como um componente fundamental para a compreensão das questões que envolvem o papel da cultura negra na sociedade brasileira, que possui influências culturais africanas em seus diversos aspectos, sendo preciso que o(a) professor(a) destaque estas contribuições e as valorize.

D

D Devista da Associação Nacional de Pós-graduação e Pesquisa em Geografia (Anpege).

$D^{D}$

p.86-122, V.15, n.28, set./dez. 2019. 
Como já afirmamos, é necessário evidenciar que a população negra foi essencial na formação do território brasileiro, para que os(as) estudantes entendam a sua contribuição na construção do país, realizada sobre mortes, sofrimento e sangue de negros(as). Geralmente, esta participação na construção do território não é reconhecida, e as influências destacadas - sobretudo, nos livros didáticos -, comumente, são apenas as dos imigrantes europeus, como os portugueses, os espanhóis e os holandeses.

O ensino dos conteúdos relacionados à constituição e ao desenvolvimento do território brasileiro é dominado por uma visão eurocêntrica em que os estudantes são incentivados a reconhecer o avanço que a civilização europeia trouxe para o Brasil e a desconhecer as contribuições que os africanos proporcionaram a este país, que foram muito mais significativas, considerando-se que foram construídas com base na mão de obra africana, com o suor e o sangue do povo que foi retirado de suas terras e escravizado pelos europeus (ANJOS, 2005).

É fundamental também que o(a) professor(a) não restrinja a abordagem dos conteúdos relacionados à questão racial apenas aos períodos em que for explicar o continente africano ou a escravidão brasileira, ou, ainda, apenas às semanas culturais. Faz-se importante inserir esses conteúdos sempre que for possível, pois diversos elementos da geografia possibilitam a inclusão da questão racial, como, por exemplo, os temas relacionados ao espaço urbano e à segregação socioespacial, evidenciando-se os locais em que a população negra reside e em quais condições, ou aqueles relacionados à cultura da população negra, destacando-se as influências africanas existentes e as comunidades remanescentes de quilombos no país.

$\mathrm{O}$ (a) professor(a) precisa apontar, explicar e contextualizar onde estão os(as) negros(as) brasileiros(as), em quais condições vivem, onde trabalham e quais as motivações e interesses que permeiam a organização da sociedade baseada na classe social e na cor. A população negra foi, historicamente, excluída, e a sociedade atual é o reflexo da discriminação e do racismo sofridos por este povo. Dessa forma, a geografia deve contemplar a questão racial, apontando as espacialidades das desigualdades raciais e socioeconômicas que permeiam a sociedade brasileira e as explicações para o cenário marcado pelo racismo que se tem, atualmente, além de tratar a diversidade cultural brasileira num contexto geográfico.

Portanto, por meio da educação e do ensino de geografia que incorporem a questão racial, é possível ensinar os(as) estudantes a respeito da população negra e da configuração histórica do Brasil, contribuindo para que reconheçam e valorizem esta população. Com base nisto, a Lei 10.639/03 será colocada em prática, auxiliando na superação da discriminação racial, do preconceito e do racismo.

D

D Devista da Associação Nacional de Pós-graduação e Pesquisa em Geografia (Anpege).

D D

p.86-122, V.15, n.28, set./dez. 2019. 
A partir da compreensão das potencialidades do ensino de geografia na discussão racial, buscamos identificar como esta abordagem tem sido realizada, e, para tanto, realizamos um estado da arte das pesquisas geográficas e a sua categorização.

\section{Categorização e unitarização dos resultados qualitativos}

Quanto à abordagem qualitativa dos resultados obtidos em nossa busca, as 29 pesquisas encontradas foram categorizadas e agrupadas em cinco categorias: 1) Lei 10.639/03, que conta com 10 pesquisas, sendo que uma delas não foi encontrada; 2) livros didáticos, que possui sete pesquisas, sendo que duas não foram encontradas; 3) propostas didático-pedagógicas, que conta com seis pesquisas; 4) representações a respeito do continente africano, que possui quatro pesquisas; e 5) ações afirmativas, que possui duas pesquisas. Os quadros 2, 3, 4, 5 e 6 apresentam os dados referentes a esta categorização. ${ }^{6}$

O Quadro 2 analisa as pesquisas que discutem a Lei 10.639/03. No total, 10 pesquisas foram enquadradas nesta categoria, sendo que uma delas, que discute a Lei 10.639/03 sob a ótica da geografia cultural, não foi encontrada.

Quadro 2 - Pesquisas que possuem como tema principal a Lei 10.639/03.

\section{CATEGORIA: Lei $10.639 / 03$}

A Lei 10.639/03 foi criada no ano de 2003, a partir da pressão do movimento negro, e torna obrigatório o ensino da história e da cultura afro-brasileira de forma positiva, destacando as contribuições da população negra no Brasil (BRASIL, 2003). Esta lei incentiva a ressignificação das práticas pedagógicas nas escolas e nas discussões que contemplem negros(as) em todos os sentidos, além de exigir a adequação dos currículos escolares.

\begin{tabular}{|c|c|c}
\hline OBJETIVO (UNIDADE) & $\begin{array}{c}\text { PALAVRAS-CHAVE } \\
\text { (SUBUNIDADES) }\end{array}$ & $\begin{array}{c}\text { TIPO DE } \\
\text { TRABALHO }\end{array}$
\end{tabular}

UN1 - "Analisar a aplicabilidade da Lei

10.639/03 no conteúdo África dos livros Geografia; livros didáticos; África. Dissertação didáticos de geografia."

UN2 - "Evidenciar as relações de poder existentes nas relações cotidianas de professores e professoras de geografia que tentam introduzir a discussão racial em seu currículo praticado."

Relações de poder; prática docente: Lei 10.639/03; ensino de geografia; currículo; cotidiano Dissertação escolar; racismo.

UN3 - "Investigar como os cursos de licenciatura em Geografia das universidades estaduais do estado do Paraná - Universidade Estadual de Currículo; educação étnicoracial; Lei $10.639 / 03$; formação Maringá (UEM) e Universidade Estadual de Londrina (UEL) - estão atuando para uma formação docente antirracista, preconizada pela lei 10.639/03."

\begin{tabular}{|c|c|c|}
\hline $\begin{array}{l}\text { UN4 - "Compreender a Lei } 10.639 / 2003 \text { e } \\
\text { sua aplicabilidade no ensino de geografia." }\end{array}$ & $\begin{array}{l}\text { Questões étnico-raciais; prática } \\
\text { do professor; Festa dos Catopês. }\end{array}$ & Dissertação \\
\hline $\begin{array}{l}\text { UN5 - "Fazemos uma análise do Currículo } \\
\text { Referencial da Rede Estadual de Goiás, } \\
\text { tentando identificar onde há o tratamento } \\
\text { das leis, e trazemos algumas possibilidades } \\
\text { para o ensino da geografia de Goiás } \\
\text { a partir dos territórios quilombolas e } \\
\text { indígenas presentes no estado." }\end{array}$ & $\begin{array}{l}\text { Ensino de geografia; relações } \\
\text { etnicorraciais; Lei 10.639/2003; } \\
\text { Lei } 11.645 / 2008 \text {. }\end{array}$ & Dissertação \\
\hline $\begin{array}{l}\text { UN6 - "Apresentar o papel da educação } \\
\text { como sujeito que rompe preconceitos." }\end{array}$ & $\begin{array}{l}\text { Educação; cidadania; preconceito; } \\
\text { Lei 10.639/2003. }\end{array}$ & $\begin{array}{l}\text { Artigo } \\
\text { científico }\end{array}$ \\
\hline $\begin{array}{l}\text { UN7 - "Indagamos a presença e a } \\
\text { ausência dos conteúdos relativos ao } \\
\text { continente africano, nos campos escolar } \\
\text { e acadêmico". }\end{array}$ & Geografia escolar; ensino; África. & $\begin{array}{l}\text { Artigo } \\
\text { científico }\end{array}$ \\
\hline $\begin{array}{l}\text { UN8 - "Questionar como está se dando a } \\
\text { sua implementação em uma escola pública." }\end{array}$ & $\begin{array}{l}\text { Relações étnico-raciais; ensino de } \\
\text { geografia; pedagogia do silêncio. }\end{array}$ & $\begin{array}{l}\text { Artigo } \\
\text { científico }\end{array}$ \\
\hline $\begin{array}{l}\text { UN9 - "Apresentar a estrutura de um } \\
\text { programa de pesquisa sobre a Lei } 10.639 \\
\text { e o ensino de geografia." }\end{array}$ & $\begin{array}{l}\text { Relações raciais e educação; } \\
\text { ensino de geografia; Lei 10.639; } \\
\text { pesquisa em ensino de geografia. }\end{array}$ & $\begin{array}{l}\text { Artigo } \\
\text { científico }\end{array}$ \\
\hline
\end{tabular}

Os objetivos e palavras-chaves que constam nos quadros foram escritos conforme a grafia que os autores usaram em suas pesquisas, inclusive com algumas imprecisões. 
FREQUÊNCIA RELATIVA DAS SUBUNIDADES

PALAVRAS-CHAVE

\begin{tabular}{|c|c|c|}
\hline $\begin{array}{l}\text { Geografia/Ensino de geografia/Geografia } \\
\text { escolar/Pesquisa em ensino de geografia }\end{array}$ & 7 & 20 \\
\hline Livros didáticos & 1 & 2,7 \\
\hline África & 2 & 5,5 \\
\hline Relações de poder & 1 & 2,7 \\
\hline $\begin{array}{l}\text { Prática docente/Formação do professor de } \\
\text { geografia/Prática do professor }\end{array}$ & 3 & 8,5 \\
\hline Lei 10.639/03 & 5 & 14 \\
\hline Currículo & 2 & 5,5 \\
\hline Cotidiano escolar & 1 & 2,7 \\
\hline Racismo & 1 & 2,7 \\
\hline $\begin{array}{l}\text { Educação étnico-racial/Questões étnico- } \\
\text { raciais/Relações etnicorraciais/Relações } \\
\text { étnico-raciais/Relações raciais e educação }\end{array}$ & 5 & 14 \\
\hline Festa dos Catopês & 1 & 2,7 \\
\hline Lei 11.645/2008 & 1 & 2,7 \\
\hline Cidadania & 1 & 2,7 \\
\hline Preconceito & 1 & 2,7 \\
\hline Educação/Ensino & 2 & 5,5 \\
\hline Pedagogia do silêncio & 1 & 2,7 \\
\hline Pesquisa em ensino de geografia & 1 & 2,7 \\
\hline
\end{tabular}

As pesquisas categorizadas como "Lei 10.639/03" discutem a respeito do cumprimento da legislação nos processos de ensino. Entendem-se a importância e o avanço proporcionados pela Lei 10.639/03, porém, é importante investigar se está sendo implementada, na prática, sendo este o levantamento que as pesquisas realizam.

Apenas dissertações e artigos científicos discutem esta temática, e todas as unidades demonstram investigar como a Lei 10.639/03 tem sido implementada, em diferentes setores relacionados à geografia, como escolas, livros didáticos, universidades e currículos. Em resumo, os resultados apontam que existem experiências de aplicação da Lei 10.639/03 que tiveram sucesso, enquanto outras ainda exigem modificações para atingirem os seus objetivos.

As subunidades apontam para a ênfase na discussão da Lei 10.639/03 a partir da formação docente, sendo necessário que os(as) professores(as) estejam preparados para incorporar a questão racial nas aulas de geografia. As relações étnico-raciais também são muito citadas, tendo em vista que essa lei proporciona que as diferenças étnico-raciais sejam ressaltadas como positivas. O currículo pode ser entendido como um documento permeado por disputa e relações de poder, sendo que, a partir da Lei 10.639/03, ele precisa ser readequado. Portanto, as pesquisas que avaliam a Lei $10.639 / 03$ são fundamentais para o incentivo a uma educação antirracista, que não incentive discursos preconceituosos e racistas. É importante que os(as) estudantes compreendam a importância dos(as) negros(as) nos processos de formação do Brasil e na manutenção da sociedade atual, além de não associarem esta população apenas à escravidão. Nesse sentido, as pesquisas categorizadas proporcionam a mudança no cenário de exclusão histórica vivenciada pelos(as) negros(as), indicando que essa lei existe para avançar na busca por relações sociais justas, e que, para tanto, a fiscalização de sua implantação é essencial. 
O Quadro 3 apresenta as pesquisas que possuem como temática principal a análise de livros didáticos. Nesta categoria, há sete pesquisas, sendo que apenas cinco foram encontradas para análise. Os dois trabalhos não encontrados versam a respeito da representação dos(as) negros(as) e da geografia africana nos livros didáticos e acerca do branqueamento da população nestes materiais.

Quadro 3 - Pesquisas que possuem como tema principal os livros didáticos.

\section{CATEGORIA: Livros didáticos}

Os livros didáticos são materiais pedagógicos gratuitos controlados pelo Estado, e que só podem ser adotados com a autorização do Ministério da Educação. Para a sua disponibilização, é necessário que os livros sejam avaliados e aprovados pelo Programa Nacional do Livro Didático (PNLD). Os livros didáticos são os materiais pedagógicos mais amplamente difundidos nas escolas públicas brasileiras, os mais utilizados pelos professores e os que, em muitos casos, são uma das únicas fontes de leitura de estudantes oriundos de classes populares. Apesar de sua importância, estes recursos são simplificados e, em muitas circunstâncias, reforçam preconceitos e estereótipos (SILVA, 2005).

\section{OBJETIVO (UNIDADE)}

PALAVRAS-CHAVE (SUBUNIDADES)
TIPO DE TRABALHO

UN1 -“Debater a forma como esse continente [africano] foi tratado pela geografia escolar presente no livro didático."

Geografia humana; ensino; livro didático; África.
Tese

UN2 - "Discutir formas de hierarquização entre os grupos raciais brancos e negros que podem atuar de modo a manter ou criar relações de dominação entre os grupos raciais, de acordo com o conceito de ideologia proposto por

Relações raciais; livro didático; ensino de geografia; Paraná (estado).

John B. Thompson."

\begin{tabular}{lll}
$\begin{array}{l}\text { UN3 - "Debater a forma com que esse } \\
\text { continente [africano] foi publicado na } \\
\text { geografia escolar do livro didático." }\end{array}$ & $\begin{array}{l}\text { Livro didático; África; } \\
\text { história do pensamento e } \\
\text { ensino. }\end{array}$ & $\begin{array}{c}\text { Artigo } \\
\text { científico }\end{array}$ \\
\hline $\begin{array}{l}\text { UN4 - "Identificar como diferentes formas } \\
\text { de manifestações de preconceito e práticas } \\
\text { discriminatórias são apresentadas em } \\
\text { livros didáticos de geografia do ensino } \\
\text { fundamental." }\end{array}$ & $\begin{array}{l}\text { Livro didático; geografia } \\
\text { discriminação. }\end{array}$ & $\begin{array}{c}\text { Artigo } \\
\text { científico }\end{array}$ \\
\hline $\begin{array}{l}\text { UN5 - "Analisar o resultado da política } \\
\text { educacional que busca garantir diversidade } \\
\text { étnico-racial em livros didáticos." }\end{array}$ & $\begin{array}{l}\text { Discurso racista; livros } \\
\text { didáticos de geografia; } \\
\text { Programa Nacional do Livro } \\
\text { Didático. }\end{array}$ & $\begin{array}{c}\text { Artigo } \\
\text { científico }\end{array}$ \\
\hline
\end{tabular}


FREQUÊNCIA RELATIVA DAS SUBUNIDADES

\section{PALAVRAS-CHAVE}

QUANTIDADE DE INCIDÊNCIA
FREQUÊNCIA RELATIVA (\%)

\begin{tabular}{lll} 
Geografia humana & 1 & 5,5 \\
\hline Ensino/Ensino de geografia/Geografia escolar & 3 & 17 \\
\hline Livro didático/Livros didáticos de geografia & 5 & 28 \\
\hline África & 2 & 11 \\
\hline Relações raciais & 1 & 5,5 \\
\hline Paraná (estado) & 1 & 5,5 \\
\hline História do pensamento e ensino & 1 & 5,5 \\
\hline Discurso/Discurso racista & 2 & 11 \\
\hline Discriminação & 1 & 5,5 \\
\hline Programa Nacional do Livro Didático & 1 & 5,5
\end{tabular}

As pesquisas categorizadas como "livros didáticos" investigam de que forma a população negra ou o continente africano são retratados nestes materiais. Os(as) autores(as) demonstram compreender a importância dos livros na formação dos(as) estudantes, uma vez que seu uso ocorre em todas as escolas públicas brasileiras. Sendo assim, é fundamental que não disseminem discursos ou imagens preconceituosas e racistas.

As pesquisas presentes nas UN1 e UN3 abordam a representação do continente africano nos livros didáticos, destacando que há um estereótipo em relação à África, que sempre é associada à fome, à pobreza e à falta de água, não sendo reconhecidos aspectos como a sua diversidade cultural. Além disso, o continente africano é pouco discutido em sala de aula, e, geralmente, o seu estudo é destinado ao fim do ano.

As UN2, UN4 e UN5 discutem a hierarquização da população negra em relação à branca, nos livros didáticos. Nos editais do PNLD, foi instituído que os livros didáticos devem respeitar e valorizar a diversidade étnica, promovendo positivamente a imagem de negros(as) (BRASIL, 2015). Nesse sentido, esses materiais de ensino precisam ser adequados, e isto é investigado pelas pesquisas, concluindo-se que não são todos os livros didáticos que estão apropriados à discussão racial, pois muitos ainda possuem imagens e discursos racistas. É fundamental que os(as) autores(as) responsáveis por sua elaboração produzam materiais justos, assim como também o PNLD deve tornar sua avaliação mais rigorosa.

As subunidades apontam para a discriminação e os discursos racistas presentes nos livros didáticos, sendo destacadas a importância do ensino de geografia na discussão racial e a necessidade de adequação dos livros de geografia para o uso em sala de aula. O continente africano é um tema frequentemente discutido, tendo em vista a sua invisibilidade nas aulas de geografia, fato comprovado por Anjos (2005).

Em suma, as pesquisas que investigam livros didáticos denunciam os estereótipos e discursos preconceituosos presentes nestes materiais, evidenciando a necessidade de adequação e de maior respeito à diversidade étnica existente no país. Os livros didáticos são recursos amplamente acessados pelos(as) estudantes e precisam ser adequados ao propósito de uma educação antirracista.

Organizado pelos autores. 
O Quadro 4 indica a análise de seis pesquisas que estabelecem propostas didáticopedagógicas que podem ser incorporadas pelos(as) professores(as) de geografia, de acordo com o seu contexto escolar. Estas proposições são essenciais, num cenário em que a maioria dos(as) professores(as) não possui formação adequada para abordar a questão racial em sala de aula.

\section{Quadro 4 - Pesquisas que estabelecem propostas didático-pedagógicas.}

\section{CATEGORIA: Propostas didático-pedagógicas.}

As pesquisas enquadradas nessa categoria discutem práticas didático-pedagógicas que buscam contemplar a questão racial no ensino de geografia, abordando temas como a Lei 10.639/03, a formação de professores(as), a educação antirracista e o uso de linguagens diferenciadas.

\section{OBJETIVO (UNIDADE)}

\section{PALAVRAS-CHAVE (SUBUNIDADES)}

UN1 - "Contribuir com o ensino da história e cultura negro-afro-brasileira e negro-africana no ensino de geografia, colaborar com a formação e a reflexão dos professores sobre o ensino das relações étnicoraciais através de proposta metodológica que utiliza o cinema Ensino de geografia; negroafrodescendente; cinema;

Dissertação educação; linguagem. como linguagem potencializadora."

UN2 - "Compreender como o ensino de geografia e a fotografia interagiram na formação de jovens do ensino médio, em uma construção coletiva de reforço de cidadania, com foco na luta contra o preconceito racial."

Fotografia; anti-racismo;

cidadania; ensino de Dissertação geografia.
UN3 - "Investigar as contribuições da geografia escolar para uma educação quilombola mediante investigação de campo sobre as práticas educativas que foram trabalhadas em sala de aula pela educadora de geografia e seus educandos."
Ensino de geografia;

educação quilombola;

currículo escolar

Dissertação

quilombola.

UN4 - "Apresentar possibilidades de ensino e aprendizagem de ações educativas de combate ao racismo e as discriminações entre o museu e a geografia escolar."

Geografia escolar; museu;

África; afro-brasileiro. Artigo científico

UN5 - "Investigar se o samba pode ser aproveitado no/para o ensino da geografia, e se esta prática pode contribuir para a implementação da Lei № 10639/03 nas Lei no 10639/03; samba; currículo; ensino de geografia.

Artigo científico escolas."

UN6 - "Construir uma estratégia para ensinar geografia em que estivessem articuladas a literatura infantil e a negritude."

Geografia; literatura infantil; Artigo igualdade étnica; poética. 


\section{FREQUÊNCIA RELATIVA DAS SUBUNIDADES}

\begin{tabular}{|c|c|c|}
\hline PALAVRAS-CHAVE & $\begin{array}{l}\text { QUANTIDADE DE } \\
\text { INCIDÊNCIA }\end{array}$ & $\begin{array}{l}\text { FREQUÊNCIA } \\
\text { RELATIVA (\%) }\end{array}$ \\
\hline $\begin{array}{l}\text { Ensino de geografia/ } \\
\text { Geografia escolar/ Geografia }\end{array}$ & 6 & 25 \\
\hline Negro-afrodescendente/afro-brasileiro & 2 & 9 \\
\hline Cinema & 1 & 4,1 \\
\hline Educação & 1 & 4,1 \\
\hline Linguagem & 1 & 4,1 \\
\hline Fotografia & 1 & 4,1 \\
\hline Anti-racismo & 1 & 4,1 \\
\hline Cidadania & 1 & 4,1 \\
\hline $\begin{array}{l}\text { Educação quilombola/ } \\
\text { Currículo escolar quilombola }\end{array}$ & 2 & 9 \\
\hline África & 1 & 4,1 \\
\hline Museu & 1 & 4,1 \\
\hline Lei $10.639 / 03$ & 1 & 4,1 \\
\hline Samba & 1 & 4,1 \\
\hline Currículo & 1 & 4,1 \\
\hline Literatura infantil & 1 & 4,1 \\
\hline Igualdade étnica & 1 & 4,1 \\
\hline Poética & 1 & 4,1 \\
\hline
\end{tabular}

A tipologia das pesquisas enquadradas nessa categoria se divide apenas entre dissertações e artigos científicos. Estes trabalhos discutem propostas didático-pedagógicas que contemplam a questão racial nos processos de ensino.

Todas as pesquisas apontam para a necessidade de uma educação antirracista, que ensine acerca das relações étnico-raciais e que possuam professores(as) que compreendam a temática para a não disseminação de discriminações e discursos preconceituosos ou racistas. Nesse sentido, a UN3 discute a educação quilombola, que exige da comunidade escolar uma preparação para lidar com a temática racial, tendo em vista que seu público é formado por estudantes que possuem maior consciência a respeito das relações raciais.

Há uma ênfase na utilização de linguagens diferenciadas e criativas que possibilitem a fuga de um ensino tradicional por meio da utilização do cinema, da fotografia, do museu, do samba, da literatura e da poesia. Nesse sentido, os trabalhos apresentam propostas que podem ser incorporadas por professores(as) de todo o Brasil, mediante a adequação ao contexto de sua escola e de seus(suas) estudantes. As subunidades evidenciam a pluralidade dessa temática e o destaque para uma educação antirracista que busca a igualdade étnica entre os grupos humanos.

Dessa forma, as pesquisas que estabelecem propostas são extremamente necessárias, uma vez que muitos(as) professores(as) não tiveram acesso a uma formação que discutiu a questão racial e que, em alguns momentos, se sentem despreparados(as) para este debate. A partir dessas sugestões, os(as) professores(as) podem encontrar formas de melhorar suas metodologias de ensino, contemplando a população negra e ainda possibilitando aulas diferenciadas aos(as) estudantes, por meio da utilização de linguagens atrativas e próximas de seus contextos.

Organizado pelos autores. 
O Quadro 5 analisa quatro pesquisas que investigam as representações a respeito do continente africano. Comumente, a África é associada a aspectos negativos, sendo que os trabalhos selecionados identificam este imaginário e apontam para a necessidade de representações justas que não reforcem estereótipos e discursos racistas.

\section{Quadro 5 - Pesquisas que investigam as representações a respeito do continente africano.}

\section{CATEGORIA: Representações a respeito do continente africano.}

Esta categoria diz respeito às representações que os sujeitos sociais e alguns documentos possuem a respeito do continente africano. Muitos(as) estudantes, sempre que pensam a respeito do continente africano, o associam à pobreza, à fome, à falta de água e ao deserto, por exemplo. Há, ainda, pessoas que falam a respeito desse continente como se fosse um país (a África). Dessa forma, as pesquisas enquadradas nesta categoria discutem qual o imaginário existente em relação à África.

\section{OBJETIVO (UNIDADE)}

\section{PALAVRAS-CHAVE (SUBUNIDADES)}

Ensino de geografia; representações sociais; África
TIPO DE TRABALHO

UN1 - "Identificar as representações sociais do continente africano presentes para os sujeitos alunos."

Geografia; África; imagens;

UN2 - "Mostrar a visibilidade da África pelos alunos, estabelecida por diversas leituras de imagens inscritas em diversos locais."

livro didático; aprendizagens.

Dissertação

UN3 - "Problematizar fotografias didáticas do continente africano presentes em livros didáticos de geografia, procurando pelos enunciados e formações discursivas que nos fazem ver a África a partir do estereótipo e Educação geográfica; livro didático; África; fotografia; Tese experimentação. da alteridade."

UN4 - "Avalia essa nuança [mapas que afirmam estereótipos negativos - geralmente, produzidos a partir do pensamento ocidental - a respeito de grupos, povos e culturas] com base na comparação de duas representações cartográficas do Império Almorávida: uma delas presente num atlas escolar brasileiro Cartografia escolar; percepção do espaço; A r t i g o imaginário ocidental; África científico negra; preconceito racial.

\section{Dissertação} e a outra, procedente de um livro didático africano." 


\section{FREQUÊNCIA RELATIVA DAS SUBUNIDADES}

\section{PALAVRAS-CHAVE}

\section{QUANTIDADE DE} INCIDÊNCIA
FREQUÊNCIA RELATIVA (\%)

\begin{tabular}{lcc}
$\begin{array}{l}\text { Ensino de geografia / Geografia } \\
\text { / Educação geográfica }\end{array}$ & 3 & 17 \\
\hline Representações sociais & 1 & 5,5 \\
\hline África/África negra & 4 & 22 \\
\hline Imagens/Fotografia & 2 & 11 \\
\hline Livro didático & 2 & 11 \\
\hline Aprendizagens & 1 & 5,5 \\
\hline Experimentação & 1 & 5,5 \\
\hline Cartografia escolar & 1 & 5,5 \\
\hline Percepção do espaço & 1 & 5,5 \\
\hline Imaginário ocidental & 1 & 5,5 \\
\hline Preconceito racial & 1 & 5,5
\end{tabular}

\section{METATEXTO}

As pesquisas categorizadas como "representações sociais a respeito do continente africano" investigam, sobretudo, como os(as) estudantes aprendem as temáticas relacionadas à África. Há uma diversidade em relação à tipologia dos trabalhos selecionados, sendo que duas dissertações, uma tese e um artigo científico discutem esta categoria.

As UN1 e UN2 versam a respeito do imaginário dos(as) estudantes acerca do continente africano, destacando que os conhecimentos se restringem aos estereótipos que são constantemente reafirmados acerca deste continente, associando-o à pobreza, à fome, à falta de água, e, até mesmo, fazendo referência a ele como a um país.

As UN3 e UN4 analisam documentos, como os livros didáticos e as representações cartográficas, sendo destacados a inadequação destes materiais e o não cumprimento de legislação que institua uma representação positiva da população negra, como a Lei 10.639/03.

As subunidades evidenciam a ênfase dada nesta categoria ao imaginário, à percepção, às imagens e às fotografias para a construção das representações dos(as) estudantes. Estes recursos, geralmente, chamam a atenção nos processos de ensino, sendo fundamental que não se apresentem apenas imagens estereotipadas acerca do continente africano, como as imagens de crianças desnutridas, por exemplo, que são frequentemente vistas nos livros didáticos.

Portanto, as pesquisas enquadradas nessa categoria ressaltam a importância de uma representação real do continente africano para que os(as) estudantes não o associem apenas a aspectos negativos. $O$ que se exige não é que se esconda a realidade de algumas regiões do continente africano, mas que se explorem também suas características positivas, como a sua diversidade cultural.

Organizado pelos autores. 
O Quadro 6 apresenta duas pesquisas categorizadas como ações afirmativas, tendo em vista que discutem as universidades e as escolas como territórios que precisam ser ocupados pela população negra, possibilitando que estas pessoas se formem como cidadãos. Esta ação pode ser realizada por meio das cotas raciais, que possibilitam aos negros(as) adentrarem as instituições de ensino superior, e por adequações no currículo escolar que proporcionem a discussão racial.

\section{Quadro 6 - Pesquisas que discutem ações afirmativas.}

\section{CATEGORIA: Açōes afirmativas.}

As ações afirmativas são políticas sociais compensatórias criadas pelo Estado a partir da demanda da sociedade. Buscam garantir o cumprimento dos direitos sociais que não estão sendo integralmente cumpridos (SILVÉRIO, 2007). Como exemplo de ações afirmativas, têm-se os diversos programas sociais do governo, e, em relação à questão racial, que está diretamente ligada à exclusão da população negra de direitos básicos, têm-se as políticas de cotas raciais implementadas em universidades públicas do país.

\begin{tabular}{|c|c|c|}
\hline OBJETIVO (UNIDADE) & $\begin{array}{c}\text { PALAVRAS-CHAVE } \\
\text { (SUBUNIDADES) }\end{array}$ & TIPO DE \\
TRABALHO
\end{tabular}

UN1 - "Analisar os processos de implantação das ações afirmativas, em especial da Universidade Estadual de Goiás (UEG) e da Universidade Federal de Goiás (UFG)".

UN2 - "Compreender como os elevados níveis de desigualdades, dos quais derivam injustiças e exclusão social, tornam-se tão evidentes quando se observa que a maior parte da população brasileira, negra, não tem condições dignas de vida que garantam a esses indivíduos a efetivação do direito de serem cidadãos."

\begin{tabular}{l|c|c}
\hline \multicolumn{3}{c}{ FREQUÊNCIA RELATIVA DAS SUBUNIDADES } \\
\hline PALAVRAS-CHAVE & QUANTIDADE DE INCIDÊNCIA & $\begin{array}{c}\text { FREQUÊNCIA } \\
\text { RELATIVA (\%) }\end{array}$ \\
\hline Ensino de geografia & 1 & $20 \%$ \\
\hline Cultura & 1 & $20 \%$ \\
\hline Negros & 1 & $20 \%$ \\
\hline Escola & 1 & $20 \%$ \\
\hline Cidadania & 1 & $20 \%$ \\
\hline
\end{tabular}

As pesquisas categorizadas como "ações afirmativas" são dissertações que versam a respeito das desigualdades existentes nas escolas públicas e nas universidades, apontando a importância das cotas raciais e a necessidade de adequações nos currículos de geografia para a contemplação da população negra.

A relação entre a questão racial e a geografia é explicitada, nessas duas pesquisas. Na UN1, a universidade é vista como um território a ser conquistado pela população negra; há uma espacialização das ações afirmativas no Brasil e o contexto da implantação de cotas nas universidades é investigado.

Na UN1, indica-se que o Brasil é permeado por desigualdades e que a população negra é privada de diversos direitos sociais básicos. O currículo é visto como um território em disputa, e se aponta para a necessidade de adequação destes documentos, assim como também dos livros didáticos, à questão racial.

Em relação às subunidades, tendo em vista que uma das pesquisas não estabelece palavraschave, a incidência das verbalizações citadas é a mesma (20\%). Estas subunidades apontam a relação intrínseca entre a população negra e a cultura, sendo que a geografia se evidencia como uma disciplina que pode contribuir nestas discussões, possibilitando a construção da cidadania nos(as) estudantes.

Portanto, essas pesquisas apontam para o cenário brasileiro injusto, indicando possibilidades de mudanças significativas, por meio da implantação de ações afirmativas e de mudanças nos currículos escolares, que, em muitos casos, não abordam a questão racial e não atendem à Lei 10.639/03.

Organizado pelos autores. 
É possível notar que há uma escassez de pesquisas em ensino de geografia que discutem a questão racial. Considerando-se a importância desta temática e as contribuições que as discussões podem proporcionar, a partir da disseminação de informações, devem ser debatidos estudos de casos que tiveram resultados positivos e podem ser aplicados em outros contextos e propostas pedagógicas para auxiliar professores(as) em suas aulas. Portanto, os(as)pesquisadores(as) de ensino de geografia precisam produzir mais conhecimentos acerca da discussão racial.

Além das categorias apresentadas, outras variáveis relacionadas à questão racial precisam ser consideradas nas pesquisas em educação, como: o preconceito e o racismo difundidos contra os(as) estudantes negros(as); as escolas que mais possuem estudantes negros(as); como os processos de ensino têm realizado essa discussão, levando em conta o contexto vivenciado; o perfil dos(as) estudantes negros(as) nas escolas; e os debates mais incisivos e específicos a respeito de como a geografia pode contribuir na superação do racismo.

Em uma trajetória de diversas publicações em ensino de geografia (1.458 artigos), o fato de apenas 29 destas discutirem a questão racial evidencia a urgência da modificação deste panorama. Tal cenário reflete os movimentos da própria sociedade, pois, à medida que as políticas públicas que contemplam a população negra vão sendo criadas, o debate a respeito deste tema tende a crescer. Além disso, conforme mais pesquisadores(as) negros(as) adentram nos campos da ciência, a temática racial passa a ser mais debatida e contemplada. Bourdieu (2004), a discutir o campo científico, afirma que o que comanda as intervenções científicas é a estrutura das relações objetivas, determinada pela distribuição do capital científico num certo contexto. Dessa forma, a posição de um agente no campo científico define suas possibilidades e impossibilidades, ou seja, os agentes caracterizados por maior volume de capital determinam o peso de outros agentes na ciência.

Faz-se importante que os(as) pesquisadores(as) atentem a temáticas pouco estudadas, como a questão racial no ensino, e produzam novos conhecimentos acerca de temas afins. À medida que mais pesquisas forem realizadas, mudanças significativas e positivas podem ser efetivadas, como o aumento da assunção da identidade negra e a diminuição do racismo e do preconceito existentes, podendo resultar, até mesmo, em sua superação e na melhoria das práticas pedagógicas, por exemplo. 


\section{Considerações finais}

Tendo em vista a importância da educação na formação dos sujeitos e na construção de suas identidades, a escola pode ser considerada como uma das instituições capazes de auxiliar na superação do racismo, assim como a geografia, tendo em vista que esta disciplina possibilita que os(as) estudantes compreendam a organização do espaço geográfico por meio da questão racial. A partir do aumento desse debate, mais pessoas terão acesso à temática, professores(as) podem ter contato com experiências já realizadas e, assim, incorporarem propostas sugeridas em suas aulas, contribuindo para a compreensão dos(as) estudantes.

Nesse sentido, o objetivo desta pesquisa foi atingido, tendo em vista que o estado da arte sobre o tema proposto foi realizado, apontando para a escassez de pesquisas acadêmicas em ensino de geografia que discutem a questão racial, no Brasil. A problemática norteadora - "como a questão racial tem sido discutida nos artigos publicados em periódicos nacionais, nas dissertações e nas teses de ensino de geografia?" - também foi respondida, e se verificou que as 29 pesquisas selecionadas se concentram em cinco temáticas principais: a Lei 10.639/03, os livros didáticos, as propostas didático-pedagógicas, as representações acerca do continente africano e as ações afirmativas.

As pesquisas que dissertam a respeito da Lei 10.639/03 investigam se esta normativa está realmente sendo implementada pelas escolas e destacam a sua importância no ensino da cultura afro-brasileira de forma positiva. Os trabalhos que abordam os livros didáticos, em sua maioria, avaliam como a população negra é representada, nestes materiais, e se discursos racistas estão sendo disseminados neles.

As pesquisas que trazem propostas didático-pedagógicas sugerem formas de se abordar a questão racial nas aulas de geografia, possuindo, geralmente, estudos de casos em que tais propostas foram aplicadas.

As pesquisas que discutem as representações acerca do continente africano criticam o fato de que a África seja pouco abordada nas aulas de geografia e de que os(as) estudantes possuam representações negativas a respeito deste continente, sempre o associando, por exemplo, à pobreza, à fome e à falta de água.

E, enfim, os trabalhos que abordam ações afirmativas destacam as desigualdades presentes na educação e apontam para a importância das cotas raciais nas universidades e das adequações sobre o tema racial nos currículos escolares de geografia.

D

D D Revista da Associação Nacional de Pós-graduação e Pesquisa em Geografia (Anpege).

D D p.86-122, V.15, n.28, set./dez. 2019. 
Dessa forma, todos os temas abordados são muito relevantes e contribuem grandemente para a discussão do racismo em sala de aula. Porém, destaca-se a importância da consideração de outras variáveis sugeridas para futuras pesquisas, como o racismo e o preconceito legitimados pela escola, as ações discriminatórias dos(as) estudantes e o perfil racial e socioeconômico dos(as) estudantes, por exemplo. É fundamental que a geografia aprofunde mais as discussões da temática racial e contribua efetivamente para a superação do racismo.

Portanto, espera-se que a presente pesquisa fomente o debate das questões raciais no ensino de geografia e nas pesquisas acadêmicas que são produzidas por pesquisadores(as) desta ciência, no Brasil. Compreender o panorama das pesquisas raciais no ensino de geografia é fundamental para se verificar quais são as temáticas mais debatidas e quais são as carências de discussões que precisam ser mais consideradas.

Trabalhos que contemplem a questão racial evidenciam-se como imprescindíveis, em um cenário em que as desigualdades raciais e socioeconômicas são estruturantes na sociedade brasileira, diariamente consolidadas e perversas, para os grupos atingidos. A cada dia, o debate racial se mostra mais urgente, no Brasil, e compreender a participação do ensino de geografia neste debate possibilita identificar assertivas e lacunas, além de apontar para a necessidade de uma formação interseccional dos(as) professores(as), de adequações necessárias nos currículos e nos livros didáticos de geografia e de mudanças que possam ser realizadas nesta disciplina e na educação como um todo.

Por fim, esta pesquisa apresentou um panorama geral da discussão racial no ensino de geografia, destacando a importância de avaliações contínuas a respeito de como o debate acerca deste tema tem sido realizado no país. Além disso, é essencial salientar a necessidade de mais estudos como este e também de outros que avaliem como a geografia tem discutido temas emergentes relativos aos demais segmentos da população que demandam atenção, como, por exemplo, as populações indígenas, as pessoas de diversas orientações sexuais e identidades de gênero (LGBTQIA+), as mulheres (negras e não negras) e as pessoas com deficiência, entre outros. 


\section{Referências}

1. ANJOS, Rafael Sanzio Araújo dos. Geografia, a África e os negros brasileiros. In: MUNANGA, Kabengele (org.). Superando o racismo na escola. $2^{\text {a }}$ ed. Brasília: Ministério da Educação/ Secretaria de Educação Continuada, Alfabetização e Diversidade, 2005, p. 173-184.

2. A África, a educação e a geografia. In: BRASIL, Secretaria de Educação Continuada, Alfabetização e Diversidade (org.). Educação antirracista: caminhos abertos pela Lei Federal n 10.639/03. Brasília: Ministério da Educação/Secretaria de Educação Continuada, Alfabetização e Diversidade, 2005, p. 167-184.

3. BARDIN, Laurence. L'analyse de contenu. $8^{\mathrm{a}}$ ed., Paris: Presses Universitaires de France, 1977.

4. BRASIL. Lei $\mathbf{n}^{\mathbf{0}} \mathbf{1 0 . 6 3 9}$, de 9 de janeiro de 2003. Altera a Lei $\mathrm{n}^{\mathrm{a}} \mathbf{9 . 3 9 4}$, de 20 de dezembro de 1996, que estabelece as diretrizes e bases da educação nacional, para incluir no currículo oficial da Rede de Ensino a obrigatoriedade da temática "História e cultura afro-brasileira”, e dá outras providências. Brasília, 2003.

5. ____ Edital de convocação para o processo de inscrição e avaliação de obras didáticas para o Programa Nacional do Livro Didático - PNDL 2018. Ministério da Educação, Brasília/DF, 2015.

6. BOURDIE, Pierre. Os usos sociais da ciência: por uma sociologia clínica do campo científico. São Paulo: Editora UNESP, 2004.

7. CAVALCANTI, Lana de Souza. Geografia escolar e a construção de conceitos no ensino. In: - Geografia, escola e construção de conhecimentos. Campinas, São Paulo: Papirus, 1998, p. 87-136.

8. CRUZ, Mariléria dos Santos. Uma abordagem sobre a história da educação dos negros. In: ROMÃO, Jeresu (org.). História da educação do negro e outras histórias. Brasília: MEC, Secretaria de Educação Continuada, Alfabetização e Diversidade, 2005. p. 21-34.

9. D’AVILA, Jerry. Diploma de brancura: política social e racial no Brasil - 1917-1945. São Paulo: Editora UNESP, 2006.

10. DAMIANI, Amélia Luisa. A geografia e a construção da cidadania. In: CARLOS, Ana Fani Alessandri (org.). A geografia na sala de aula. 8ª ed., São Paulo: Contexto, 2006, p. 50-61.

11. DOMINGUES, Petrônio. O mito da democracia racial e a mestiçagem em São Paulo no pós-abolição (1989-1930). In: Tempos Históricos, Marechal Cândido Rondon, v. 5 , n. 6, p. 275-292, 2004.

D 
12. . Movimento Negro Brasileiro: alguns apontamentos históricos. In: Tempo, Rio de Janeiro, v. 12, n. 23, p. 100-122, 2007.

13. FERREIRA, N. S. de A. As pesquisas denominadas “estado da arte”. In: Educação \& Sociedade, Campinas, v. 23, n. 79, p. 257-272, 2002.

14. FONSECA, Ricardo Lopes; SALVI, Rosana Figueiredo; TORRES, Eloiza Cristiane. O estado da arte das pesquisas em dissertações de mestrado em ensino de geografia: contribuição para uma avaliação a partir das pesquisas nos programas nacionais de stricto sensu (2008-2012). In: Anpege, Rio de Janeiro, v. 10, n. 13, p. 141-163, jan./jul. 2014.

15. Avaliação da preparação de graduandos de Geografia para a inclusão de alunos com necessidades educacionais especiais. Tese (Doutorado em Geografia). Universidade Estadual de Londrina, Londrina, 2015, 183 f.

16. GLASS, Ronald D. Entendendo raça e racismo: por uma educação racialmente crítica e antirracista. In: Estudos Pedagógicos, Brasília, v. 93, n. 235, p. 883-913, set./dez. 2012.

17. GOMES, Nilma Lino. Educação e identidade negra. In: Aletria, Belo Horizonte, v. 9, p. 38-47, 2002.

18. .Educação e relações raciais: refletindo sobre algumas estratégias de atuação. In: MUNANGA, Kabengele (org.). Superando o racismo na escola. $2^{\text {a }}$ ed., Brasília: Ministério da Educação, Secretaria de Educação Continuada, Alfabetização e Diversidade, 2005, p. $143-154$.

19. Movimento Negro e educação: ressignificando e politizando a raça. In: Educação e Sociedade, Campinas, v. 33, n. 120, p. 727-744, jul./set. 2012.

20. GONÇALVES, Luiz Alberto Oliveira; SILVA, Petronilha Beatriz Gonçalves. Movimento Negro e educação. In: Revista Brasileira de Educação, Rio de Janeiro, n. 15, p. 134-158, set./dez. 2000.

21. IBGE. População chega a 205,5 milhões, com menos brancos e mais pardos e pretos. 2017a. Disponível em: <https://agenciadenoticias.ibge.gov.br/agencia-noticias/2012agencia-de-noticias/noticias/18282-pnad-c-moradores.html>. Acesso em: 20 jun. 2018.

22. PNAD Contínua 2016: 51\% da população com 25 anos ou mais do Brasil possuíam apenas o ensino fundamental completo. 2017b. Disponível em: <https:// agenciadenoticias.ibge.gov.br/agencia-sala-de-imprensa/2013-agencia-de-noticias/ releases/18992-pnad-continua-2016-51-da-populacao-com-25-anos-ou-mais-dobrasil-possuiam-apenas-o-ensino-fundamental-completo>. Acesso em: 16 mar. 2019. 
23. OLIVEIRA, Leyla Beatriz de Sá; CUNHA JÚNIOR, Henrique Antunes. A importância da lei federal no. 10.639/03. In: África e Africanidades, Rio de Janeiro, v. 4, n. 16/17, p. 1-6, fev./maio 2012.

24. QUIJANO, Anibal. Colonialidad y modernidade/racionalidade. In: Peru indígena, v. 13, n. 29, p. 11-20, 1992.

25. Colonialidade do poder, eurocentrismo e América Latina. In: CLACSO, Conselho Latinoamericano de Ciências Sociais. A colonialidade do saber: eurocentrismo e ciências sociais - perspectivas latino-americanas. $1^{\text {a }}$ ed., Buenos Aires: CLACSO, 2005, p. 117-142.

26. SANT' ANA, Antonio Olimpio. História e conceitos básicos sobre o racismo e seus derivados. In: MUNANGA, Kabengele (org.). Superando o racismo na escola. $2^{\text {a }}$ ed., Brasília: Ministério da Educação, Secretaria de Educação Continuada, Alfabetização e Diversidade, 2005, p. 39-67.

27. SANTOS, Renato Emerson dos. Ensino de geografia e currículo: questões a partir da Lei 10.639. In: Terra Livre, São Paulo, n. 34, v. 1, p. 141-160, jan./jun. 2010.

28. . A Lei 10.639 e o ensino de geografia: construindo uma agenda de pesquisaação. In: Tamoios, Rio de Janeiro, v. 7, n. 1, p. 4-24, 2011.

29. SILVA, Maria Nilza da. O negro no Brasil: um problema de raça ou de classe?. In: Mediações, Londrina, v. 5, n. 2, p. 99-124, jul./dez. 2000.

30. SILVÉRIO, Valter Roberto. Ação afirmativa: uma política pública que faz a diferença. In: PACHECO, Jairo Queiroz; SILVA, Maria Nilza da (orgs.). O negro na universidade: o direito à inclusão. Brasília, DF: Fundação Cultural Palmares, 2007, p. 21-50.

31. SOUSA, Robson Simplicio de; GALIAZZI, Maria do Carmo. A categoria na análise textual discursiva: sobre método e sistema em direção à abertura interpretativa. In: Revista Pesquisa Qualitativa, São Paulo, v. 5, n. 9, p. 514-538, dez. 2017.

32. WIEVIORKA, Michel. O racismo, uma introdução. São Paulo: Perspectiva, 2007. 